\title{
Spatial and seasonal variability of $\mathrm{PM}_{2.5}$ acidity at two Chinese megacities: insights into the formation of secondary inorganic aerosols
}

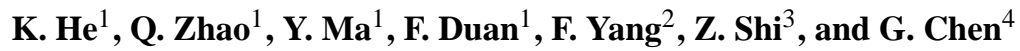 \\ ${ }^{1}$ State Key Joint Laboratory of Environment Simulation and Pollution Control, School of Environment, Tsinghua University, \\ Beijing 100084, China \\ ${ }^{2}$ Key Laboratory of Computational Geodynamics, College of Earth Science, Graduate University of Chinese Academy of \\ Sciences, Beijing 100049, China \\ ${ }^{3}$ School of Geography, Earth and Environmental Science, University of Birmingham, Edgbaston Birmingham B15 2TT, UK \\ ${ }^{4}$ Chongqing Environmental Protection Bureau, Chongqing 401147, China
}

Correspondence to: K. He (hekb@tsinghua.edu.cn)

Received: 30 August 2011 - Published in Atmos. Chem. Phys. Discuss.: 13 September 2011

Revised: 11 January 2012 - Accepted: 24 January 2012 - Published: 6 February 2012

\begin{abstract}
Aerosol acidity is one of the most important parameters influencing atmospheric chemistry and physics. Based on continuous field observations from January 2005 to May 2006 and thermodynamic modeling, we investigated the spatial and seasonal variations in $\mathrm{PM}_{2.5}$ acidity in two megacities in China, Beijing and Chongqing. Spatially, $\mathrm{PM}_{2.5}$ was generally more acidic in Chongqing than in Beijing, but a reverse spatial pattern was found within the two cities, with more acidic $\mathrm{PM}_{2.5}$ at the urban site in Beijing whereas the rural site in Chongqing. Ionic compositions of $\mathrm{PM}_{2.5}$ revealed that it was the higher concentrations of $\mathrm{NO}_{3}^{-}$at the urban site in Beijing and the lower concentrations of $\mathrm{Ca}^{2+}$ within the rural site in Chongqing that made their $\mathrm{PM}_{2.5}$ more acidic. Temporally, $\mathrm{PM}_{2.5}$ was more acidic in summer and fall than in winter, while in the spring of 2006, the acidity of $\mathrm{PM}_{2.5}$ was higher in Beijing but lower in Chongqing than that in 2005. These were attributed to the more efficient formation of nitrate relative to sulfate as a result of the influence of Asian desert dust in 2006 in Beijing and the greater wet deposition of ammonium compared to sulfate and nitrate in 2005 in Chongqing. Furthermore, simultaneous increase of $\mathrm{PM}_{2.5}$ acidity was observed from spring to early summer of 2005 in both cities. This synoptic-scale evolution of $\mathrm{PM}_{2.5}$ acidity was accompanied by the changes in air masses origins, which were influenced by the movements of a subtropical high over the northwestern Pacific in early summer. Finally, the correlations between
\end{abstract}

$\left[\mathrm{NO}_{3}^{-}\right] /\left[\mathrm{SO}_{4}^{2-}\right]$ and $\left[\mathrm{NH}_{4}^{+}\right] /\left[\mathrm{SO}_{4}^{2-}\right]$ suggests that under conditions of high aerosol acidity, heterogeneous reactions became one of the major pathways for the formation of nitrate at both cities. These findings provided new insights in our understanding of the spatial and temporal variations in aerosol acidity in Beijing and Chongqing, as well as those reported in other cities in China.

\section{Introduction}

Acidic aerosols can increase the risks to human health by direct inhalation and indirectly by activating hazardous particulate materials (Amdur and Chen, 1989; Health Effects Institute, 2002). Wet/dry deposition of acidic aerosols also lead to severe degradation of ecosystems (Larssen et al., 2006). Most acidic aerosols are hygroscopic, and as such act to reduce atmospheric visibility (Watson, 2002) as well as disturbing the radiative balance of the atmosphere (Boucher and Anderson, 1995; Crumeyrolle et al., 2008). They are also of great importance to atmospheric chemistry through their influence on many heterogeneous reactions and the behaviors of reactants and oxidants (Seinfeld and Pandis, 1998; Jang et al., 2002). Aerosol acidity can also affect the solubility of iron and phosphorus in the atmospheric aerosols (Meskhidze et al., 2005; Shi et al., 2011; Nenes et al., 2011), which has

Published by Copernicus Publications on behalf of the European Geosciences Union. 
important implications for ocean biogeochemistry and global climate change (Jickells et al., 2005).

Acidic aerosol species in cities are usually dominated by sulfate $\left(\mathrm{SO}_{4}^{2-}\right)$ and nitrate $\left(\mathrm{NO}_{3}^{-}\right)$, mostly converted from the precursors $\mathrm{SO}_{2}$ and $\mathrm{NO}_{\mathrm{x}}$, respectively, and are partly or fully neutralized by ammonium $\left(\mathrm{NH}_{4}^{+}\right)$and basic cations such as $\mathrm{Ca}^{2+}$ and $\mathrm{Mg}^{2+}$. $\mathrm{Na}^{+}$and $\mathrm{Cl}^{-}$may also be important species influencing aerosol acidity in coastal area where sea salt plays a role. Aerosol acidity cannot be directly measured due to its low water content (Meng et al., 1995; Nenes et al., 1998), and is generally assessed using three different kinds of parameters, namely, strong acidity, ion-balanced acidity and in situ acidity.

Strong acidity, measured from the aqueous extracts of aerosol samples, represents the absolute acidity of the aerosols, but it cannot show any in situ characteristics due to the large excesses of water (Pathak et al., 2004). Ionbalanced acidity refers to the estimation of $\mathrm{H}^{+}$concentration by subtracting the equivalent cations, other than $\mathrm{H}^{+}$, from anions (Zhang et al., 2007a). It is more widely used in a relative way to indicate the neutralizing level with the equivalent ratio of cations/anions (Adams et al., 1999; Zhang et al., 2002, 2007a; Chu et al., 2004; Sun et al., 2010; Johansen et al., 1999; Takami et al., 2007; Chou et al., 2008). In situ aerosol acidity, in the form of the concentration of free $\mathrm{H}^{+}$ or $\mathrm{pH}$ in the deliquesced particles at the ambient condition, is most likely to influence the chemical behavior of aerosols. It can be estimated from a variety of thermodynamic models, such as E-AIM, SCAPE and GFEMN (Pathak et al., 2004, 2009; Yao et al., 2006; Takahama et al., 2006; Zhang et al., 2007a). However, it should be noted that ion-balanced and in situ aerosol acidity are empirical approaches that both depend on the choice of ion species. For example, due to their low abundance relative to ammonium in fine particles, basic $\mathrm{Ca}^{2+}$ and $\mathrm{Mg}^{2+}$ are usually ignored in the estimation of aerosol acidity, which might be less appropriate during dust events (Ziemba et al., 2007).

The characteristics of aerosol acidity may vary from region to region due to the spatiotemporal variability in the emission of primary aerosols and gaseous precursors, as well as regional differences in the climatic driving forces. The earliest observations on aerosol acidity in China were initiated in the 1980s in regions in the south and southwest (Huang et al., 1988; Shen et al., 1992; Zhao et al., 1994), but they generally focused on the acidification of fog and cloud in respect to severe acid rain, with most of the sites located in rural and remote areas. In recent years in China, there have been many field observations on aerosol acidity in the megacities of different regions, such as Beijing (Yao et al., 2002; Dillner et al., 2006; Sun et al., 2010), Shanghai (Yao et al., 2002; Xiu et al., 2005; Wang et al., 2006), Hong Kong (Pathak et al., 2003, 2004a, b) and Chongqing (Quan and Zhang, 2008; Aas et al., 2007).
While these studies suggest a general pattern of higher acidity in southern China than in the north, only a few of them presented parallel inter-region comparisons, with little information on seasonal variation. For example, Wang et al. (2006) and Pathak et al. (2009) investigated aerosol acidity at different regions in China, in spring and summer, respectively. Moreover, even for a specific region, there are large discrepancies between the studies. For Shanghai, Xiu et al. (2005) found that aerosols were almost completely neutralized, a finding that is contrary to the results reported by Yao et al. (2002) and Wang et al. (2006) (Chan and Yao, 2008). The discrepancies might be attributed to a variety of factors, including the procedures of sampling analysis and changes in emission strength and meteorological condition. Increasingly there is a need to understand how these factors have influenced the variability of aerosol acidity.

Along with the increase in domestic $\mathrm{NO}_{\mathrm{x}}$ emissions in recent years (Zhang et al., 2007b), the concentration and proportion of $\mathrm{NO}_{3}^{-}$in aerosols have been found to have increased significantly in most Chinese megacities (Richter et al., 2005; Chan and Yao, 2008; Shen et al., 2008), and become a major concern in the acidity of aerosols as well as their wet/dry deposition (Han et al., 2006; Larssen et al., 2006; Song et al., 2008). The formation pathway of $\mathrm{NO}_{3}^{-}$ depends on not only the availability of $\mathrm{NH}_{4}^{+}$and meteorological condition (such as temperature), but also the characteristics of the preexisting particles, such as aerosol acidity, water content and alkaline mineral composition (Pakkanen et al., 1996; Hu and Abbatt, 1997; John et al., 1990; Zhuang et al., 1999). In particular, Pathak et al. (2009) recently reported high concentration of $\mathrm{NO}_{3}^{-}$with high acidity and low $\mathrm{NH}_{4}^{+}$ at Beijing and Shanghai, with their formation being largely attributed to the hydrolysis of $\mathrm{N}_{2} \mathrm{O}_{5}$ on the preexisting particles. This differs from the findings of most previous field observations, which indicated that high concentration of $\mathrm{NO}_{3}^{-}$ are found in association with high $\mathrm{NH}_{4}^{+}$(Pathak et al., 2009). However, the observations of Pathak et al. (2009) were limited to summertime.

In this study, the aerosol acidity at Beijing and Chongqing, two megacities in northern and southwestern China, respectively, was examined in parallel during a 15 -month period of field observation, and the characteristics of fine particles $\left(\mathrm{PM}_{2.5}\right.$, particles of aerodynamic diameter $\left.<2.5 \mu \mathrm{m}\right)$ were investigated in detail. Based on the measurements of ionbalanced and in situ acidity, we investigated the spatial and seasonal patterns of $\mathrm{PM}_{2.5}$ acidity at these two cities. We also discussed the factors that determined these spatial and temporal variations. 


\section{Experimental method and model description}

\subsection{Sampling and analysis}

Weekly $\mathrm{PM}_{2.5}$ samples were collected at both urban and rural sites of Beijing and Chongqing using a three-channel lowflow sampler (Aerosol Dynamics Inc., Berkeley, CA). Details of the sampling sites have been provided previously (He et al., 2001; Zhao et al. 2010). In brief, the urban and rural sites at Beijing were inside Tsinghua University $\left(\mathrm{TH}, 40^{\circ} 19^{\prime} \mathrm{N}\right.$, $116^{\circ} 19^{\prime} \mathrm{E}$ ) and near the Miyun Reservoir (MY, $40^{\circ} 29^{\prime} \mathrm{N}$, $116^{\circ} 47^{\prime} \mathrm{E}$ ), respectively, with a distance of $70 \mathrm{~km}$ between them. Three sites were selected at Chongqing, including a residential urban site in Jiangbei District (JB, $29^{\circ} 34^{\prime} \mathrm{N}$, $106^{\circ} 32^{\prime} \mathrm{E}$ ), an industrial site in Dadukou District (DDK, $29^{\circ} 29^{\prime} \mathrm{N}, 106^{\circ} 29^{\prime} \mathrm{E}$ ), and a rural site near the Jinyun Mountain in the Beibei District $\left(\mathrm{BB}, 29^{\circ} 50^{\prime} \mathrm{N}, 106^{\circ} 25^{\prime} \mathrm{E}\right)$, which is $30 \mathrm{~km}$ and $40 \mathrm{~km}$ away from JB and DDK, respectively.

The sampling procedure was also given by $\mathrm{He}$ et al. (2001). Operating at a flow rate of $0.41 \mathrm{~min}^{-1}$, one of the three channels collected $\mathrm{PM}_{2.5}$ on a Teflon filter with a Teflon impactor followed by a glass denuder. The glass denuder is coated with a $2 \%$ carbonate solution prepared in 50:50 water:methanol to remove the acidic gases. $\mathrm{HNO}_{3}$ volatilized from the Teflon filter is collected on a nylon filter. Hence water soluble ions are determined from this Teflon filter but the reported particulate $\mathrm{NO}_{3}^{-}$is the sum of $\mathrm{NO}_{3}^{-}$on both the Teflon and nylon filters. The other two channels collected $\mathrm{PM}_{2.5}$ with a single Teflon filter and quartz filter for measuring elements and carbonaceous components, respectively, which were not used in this study. Each sample was collected continuously for a week. From 28 January 2005 to 5 May 2006, 106 and $180 \mathrm{PM}_{2.5}$ samples were collected at Beijing and Chongqing, respectively.

Mass concentrations of $\mathrm{PM}_{2.5}$ were obtained by weighing on an analytical balance (Mettler Toledo AG285), after stabilizing under constant temperature $\left(20 \pm 5^{\circ} \mathrm{C}\right)$ and humidity $(40 \pm 5 \%)$. Eight ions, including $\mathrm{SO}_{4}^{2-}, \mathrm{NO}_{3}^{-}, \mathrm{Cl}^{-}$, $\mathrm{NH}_{4}^{+}, \mathrm{K}^{+}, \mathrm{Ca}^{2+}, \mathrm{Na}^{+}$and $\mathrm{Mg}^{2+}$, were measured by ion chromatography (Dionex 600, details in Wang et al., 2005).

Hourly meteorological data for both Beijing and Chongqing were obtained from the website http://www. wunderground.com, including temperature, dewpoint, wind speed, visibility and precipitation. The spatial distribution of geopotential height was derived from the archived meteorological data of NOAA's Air Resources Laboratory (ARL, http://ready.arl.noaa.gov/).

\subsection{Indicators of $\mathrm{PM}_{2.5}$ acidity}

\subsubsection{Ratio of cation/anion}

In this study, the equivalent charge ratio (eq/eq) of the major cations $\mathrm{NH}_{4}^{+}$and $\mathrm{Ca}^{2+}$ to anions $\mathrm{SO}_{4}^{2-}$ and $\mathrm{NO}_{3}^{-}$was used to indicate the neutralizing level of $\mathrm{PM}_{2.5}$, as the other ions generally had little influence on the acidity at Beijing and Chongqing (to be discussed in Sect. 3.1). The equivalent charge ratio was defined as following (Adams et al., 1999; Zhang et al., 2002):

$\mathrm{R}_{\mathrm{C} / \mathrm{A}}=\frac{\mathrm{NH}_{4}^{+}+\mathrm{Ca}^{2+}}{\mathrm{SO}_{4}^{2-}+\mathrm{NO}_{3}^{-}}$

where all the species denote the concentrations of their equivalent charges (likewise for all the ratios of species without brackets in the following text). In this equation, $R_{C / A} \geq 1$ indicates that most of the acids can be neutralized, while $R<1$ indicates the aerosol is acidic.

\subsubsection{In situ aerosol acidity}

Both free $\mathrm{H}^{+}$concentration $\left(\left[\mathrm{H}^{+}\right]_{\text {Ins }}\right.$, the square brackets indicate the molar concentration of the species inside, used here and henceforth) and in situ $\mathrm{pH}$ in the deliquesced particles were used as indicators of aerosol acidity, which can be estimated from a chemical thermodynamic model (EAIM2, http://www.aim.env.uea.ac.uk/aim/). E-AIM2 is a state-of-the-art model that can accurately simulate the liquid and solid phase of ionic compositions in the mixing system $\mathrm{H}^{+}-\mathrm{NH}_{4}^{+}-\mathrm{SO}_{4}^{2-}-\mathrm{NO}_{3}^{-}-\mathrm{H}_{2} \mathrm{O}$ at a given temperature and relative humidity (Clegg et al., 1998). The model input of E-AIM2 includes weekly averaged temperature, relative humidity, $\left[\mathrm{SO}_{4}^{2-}\right],\left[\mathrm{NO}_{3}^{-}\right],\left[\mathrm{NH}_{4}^{+}\right]$and total $\mathrm{H}^{+}\left(\left[\mathrm{H}^{+}\right]\right.$Total $)$, which is estimated from the ionic balance of the relevant species (Yao et al., 2006; Zhang et al., 2007; Pathak et al., 2009):

$\left[\mathrm{H}^{+}\right]_{\text {Total }}=2 \times\left[\mathrm{SO}_{4}^{2-}\right]+\left[\mathrm{NO}_{3}^{-}\right]-\left[\mathrm{NH}_{4}^{+}\right]$

The aerosol $\mathrm{pH}$ was calculated as:

In situ aerosol $\mathrm{pH}=-\log \left(\gamma \times\left[\mathrm{H}^{+}\right]_{\text {Frac }}\right)$

where $\gamma$ is the activity coefficient on mole fraction basis and $\left[\mathrm{H}^{+}\right]_{\text {Frac }}$ is the molar fractions of aqueous phase $\mathrm{H}^{+}$(Zhang et al., 2007a). In addition to these two parameters, $\left[\mathrm{H}^{+}\right]_{\text {Ins }}$ and the concentration of water content $\left(\left[\mathrm{H}_{2} \mathrm{O}\right]\right)$ were derived from E-AIM2.

The lack of information about the organic acids generally has little influence on the estimation of aerosol acidity due to their low abundance in aerosols (Zhang et al., 2007a; Pathak et al., 2009). However, larger bias may exist because of a lack of information about basic $\mathrm{Ca}^{2+}$ and $\mathrm{Mg}^{2+}$, especially in samples containing high concentrations of mineral dust (Ziemba et al., 2007). Although there are models, such as SCAPE, that take into account a system with these basic ions included, they cannot be used in the current study because the required gaseous $\mathrm{HNO}_{3}$ and $\mathrm{NH}_{3}$, the input parameters for the models, were not measured here. It should also be noted that the E-AIM2 model only simulates the average results over the whole week without considering the influence from temporal variations in aerosol composition, temperature and relative humidity (Yao et al., 2006). 


\subsection{Trajectory computation and clustering}

Backward trajectories of air masses arriving at Beijing and Chongqing were calculated using the HYSPLIT model (Version 4.8) to investigate the influence of different air masses on aerosol composition and acidity. The meteorological data fields used to run the model are 6-hourly FNL archived data, which are available at NOAA's ARL archives. For single trajectory calculation, the model was run 4 times per day (UTC 00:00, 06:00, 12:00 and 18:00) with the arrival level at $500 \mathrm{~m}$ (below the boundary layer) or $2000 \mathrm{~m}$ (above the boundary layer).

As the typical errors of individual trajectories were estimated to be $20 \%$ of the traveled distance (Stohl, 1998), the trajectories over the whole sampling period were classified into seasonal transport patterns using the HYSPLIT model. A detailed procedure of the clustering analysis is provided in the supplementary material according to the model description (Draxler et al., 2006). The percentage change in total spatial variance (TSV) was used to determine what is the reasonable number of clusters in each season: a large increase in TSV indicates that different clusters are being paired and therefore that the cluster process should stop.

\section{Results and discussions}

\subsection{Abundance of ionic species in $\mathbf{P M}_{2.5}$}

The annual concentrations of $\mathrm{PM}_{2.5}$ and ionic species were averaged from March 2005 to February 2006 for Beijing and Chongqing, as shown in Table 1. $\mathrm{PM}_{2.5}$ mass concentration was similar at all the three sites in Chongqing $\left(\sim 130 \mu \mathrm{g} \mathrm{m}^{-3}\right)$, all of which were higher than those at Beijing $\left(118 \mu \mathrm{g} \mathrm{m}^{-3}\right.$ for $\mathrm{TH}$ and $68 \mu \mathrm{g} \mathrm{m}^{-3}$ for MY). This indicates high regional background levels of $\mathrm{PM}_{2.5}$ in the surrounding area in Chongqing. As with $\mathrm{PM}_{2.5}$ mass, higher concentrations of total ionic species were found in Chongqing (41.3-45.0 $\mathrm{g} \mathrm{m}^{-3}$ ) than in Beijing (28.3$39.1 \mu \mathrm{g} \mathrm{m}^{-3}$ ). The proportion of ionic species in $\mathrm{PM}_{2.5}$ at the urban site in Beijing (33.0\%) was close to those at Chongqing (31.8-34.9\%), but the higher fraction in MY $(41.4 \%)$ suggests a more important role of ionic species in rural areas of Beijing. Components other than ionic species contributed similar amounts to $\mathrm{PM}_{2.5}$ at Beijing and Chongqing, i.e. carbonaceous species and crustal dust accounted for $36-40 \%$ and 6-8 \% of $\mathrm{PM}_{2.5}$ mass, respectively (Zhao et al., 2010; He et al., 2011).

$\mathrm{SO}_{4}^{2-}, \mathrm{NO}_{3}^{-}$and $\mathrm{NH}_{4}^{+}$dominated the ionic species, with a contribution of up to $85-90 \%$ at both Beijing and Chongqing. As with $\mathrm{PM}_{2.5}$ at Chongqing, the three species when considered in combination had a small spatial variation, while at Beijing their relatively small difference between MY and TH (MY/TH: 76.8\%) compared to $\mathrm{PM}_{2.5}$ (MY/TH: $57.7 \%$ ) indicates that they are of greater regional significance than the other aerosol species. Concentrations of $\mathrm{SO}_{4}^{2-}$ for all the sites were higher at Chongqing than at Beijing, whereas $\mathrm{NO}_{3}^{-}$showed the opposite spatial pattern with higher concentrations at Beijing than at Chongqing. This is mainly attributed to regional differences in energy structure and meteorology (see Sect. 3.2). At the mean time, it should be noted that a higher proportion of $\mathrm{SO}_{4}^{2-}$ in $\mathrm{PM}_{2.5}$ was found for MY (0.19) than TH (0.13), but similar as that for the sites in Chongqing (0.18-0.20). This was probably due to the more homogeneous spatial distribution of sulfate in Beijing than the other aerosol species, as has been found by other studies (Zhao et al., 2009; Guo et al., 2010). It also indicates that the regional influence of sulfate in Beijing was as important as in Chongqing.

Compared to the above major ionic species, $\mathrm{Ca}^{2+}, \mathrm{Mg}^{2+}$, $\mathrm{Na}^{+}, \mathrm{K}^{+}$and $\mathrm{Cl}^{-}$constituted a minor fraction (10-15\%) of ionic species at Beijing and Chongqing. The annual concentrations of basic $\mathrm{Ca}^{2+}$ and $\mathrm{Mg}^{2+}$ were higher at Chongqing (totaling 0.9-1.5 $\mathrm{g} \mathrm{m}^{-3}$ ) than at Beijing (totaling $\left.0.7-1.1 \mu \mathrm{g} \mathrm{m}^{-3}\right)$. Their low abundance relative to $\mathrm{NH}_{4}^{+}$ suggests that they have only a weak influence on neutralizing the acidic species, as found in most studies on aerosol acidity (Yao et al., 2006; Zhang et al., 2007a; Pathak et al., 2009). However, as an indicator of mineral dust, which was found in high concentrations during the spring and winter at Beijing and Chongqing (Zhao et al., 2010), $\mathrm{Ca}^{2+}$ was included in the acidity analysis to get an idea of the regional influence of alkaline dust.

$\mathrm{Cl}^{-}$was relatively abundant at all the sites (0.4$\left.2.2 \mu \mathrm{g} \mathrm{m}^{-3}\right)$, and primarily comes from coal combustion (Yao et al., 2002) and biomass burning (Li et al., 2007, 2009). Similarly, $\mathrm{Na}^{+}\left(0.3-0.7 \mu \mathrm{g} \mathrm{m}^{-3}\right)$ and $\mathrm{K}^{+}\left(1.4-3.1 \mu \mathrm{g} \mathrm{m}^{-3}\right)$ mainly come from coal combustion and biomass burning, respectively, as revealed by our previous study (Zhao et al., 2010). These three ions were excluded in the following acidity analysis due to their neglectable effect on aerosol acidity.

\subsection{Spatiotemporal variations in cation/anion ratio}

\subsubsection{Spatial distribution}

The ratio of cation/anion $\left(\mathrm{R}_{\mathrm{C} / \mathrm{A}}\right)$ in $\mathrm{PM}_{2.5}$ was calculated for all the sites according to Eq. (1). As shown in Table 1, annual $\mathrm{R}_{\mathrm{C} / \mathrm{A}}$ from March 2005 to February 2006 were 0.97 and 1.04 at TH and MY, respectively, whereas those in Chongqing were substantially lower, ranging from 0.76 to 0.86 , respectively. This indicates that the aerosols were much more acidic at Chongqing than at Beijing. This pattern is consistent with the findings of Wang et al. (2006), who reported that aerosols over southern China were less neutralized during springtime than aerosols over northern China.

The regional distribution of $\mathrm{PM}_{2.5}$ acidity was mainly caused by the regional differences in the abundance of $\mathrm{NH}_{4}^{+}$ relative to $\mathrm{NO}_{3}^{-}$and $\mathrm{SO}_{4}^{2-}$, as revealed from the low ratio of $\mathrm{Ca}^{2+} / \mathrm{NH}_{4}^{+}$at all sites (0.06-0.08, equivalent charge ratio); 
Table 1. Annual mass concentrations of $\mathrm{PM}_{2.5}$, its major ionic species and their equivalent ratios at Beijing and Chongqing from March 2005 to February 2006.

\begin{tabular}{|c|c|c|c|c|c|}
\hline \multirow[t]{2}{*}{$\mathrm{PM}_{2.5}$ species } & \multicolumn{3}{|c|}{ Chongqing } & \multicolumn{2}{|c|}{ Beijing } \\
\hline & JB & DDK & BB & $\mathrm{TH}$ & MY \\
\hline Number of samples & 48 & 49 & 43 & 43 & 42 \\
\hline $\mathrm{PM}_{2.5}\left(\mu \mathrm{g} \mathrm{m}^{-3}\right)$ & $129.0 \pm 42.6$ & $133.7 \pm 44.1$ & $126.1 \pm 43.4$ & $118.5 \pm 40.6$ & $68.4 \pm 24.7$ \\
\hline $\mathrm{SO}_{4}^{2-}\left(\mu \mathrm{g} \mathrm{m}^{-3}\right)^{-}$ & $25.5 \pm 9.1$ & $23.4 \pm 8.4$ & $23.9 \pm 8.9$ & $15.7 \pm 10.5$ & $13.0 \pm 9.3$ \\
\hline $\mathrm{NO}_{3}^{-}\left(\mu \mathrm{g} \mathrm{m}^{-3}\right)$ & $5.3 \pm 3.6$ & $5.0 \pm 3.3$ & $4.8 \pm 3.0$ & $10.1 \pm 6.2$ & $6.4 \pm 4.9$ \\
\hline $\mathrm{NH}_{4}^{+}\left(\mu \mathrm{g} \mathrm{m}^{-3}\right)$ & $7.9 \pm 3.8$ & $7.7 \pm 3.5$ & $7.3 \pm 3.9$ & $7.4 \pm 4.2$ & $6.1 \pm 3.4$ \\
\hline $\mathrm{Ca}^{2+}\left(\mu \mathrm{g} \mathrm{m}^{-3}\right)$ & $1.1 \pm 0.7$ & $1.2 \pm 0.6$ & $0.7 \pm 0.4$ & $0.9 \pm 0.4$ & $0.5 \pm 0.3$ \\
\hline $\mathrm{Cl}^{-}\left(\mu \mathrm{g} \mathrm{m}^{-3}\right)$ & $1.8 \pm 1.8$ & $1.6 \pm 1.5$ & $0.8 \pm 0.9$ & $2.2 \pm 2.3$ & $0.4 \pm 0.6$ \\
\hline $\mathrm{Na}^{+}\left(\mu \mathrm{g} \mathrm{m}^{-3}\right)$ & $0.7 \pm 0.2$ & $0.7 \pm 0.24$ & $0.5 \pm 0.1$ & $0.5 \pm 0.2$ & $0.3 \pm 0.2$ \\
\hline $\mathrm{Mg}^{2+}\left(\mu \mathrm{g} \mathrm{m}^{-3}\right)$ & $0.2 \pm 0.1$ & $0.3 \pm 0.1$ & $0.2 \pm 0.1$ & $0.2 \pm 0.1$ & $0.2 \pm 0.1$ \\
\hline $\mathrm{K}^{+}\left(\mu \mathrm{g} \mathrm{m}^{-3}\right)$ & $2.5 \pm 0.9$ & $2.6 \pm 1.3$ & $3.1 \pm 1.5$ & $2.1 \pm 1.2$ & $1.4 \pm 0.8$ \\
\hline Sum of ionic species $\left(\mu \mathrm{g} \mathrm{m}^{-3}\right)$ & $45.0 \pm 28.7$ & $42.5 \pm 26.2$ & $41.3 \pm 24.6$ & $39.1 \pm 22.1$ & $28.3 \pm 20.3$ \\
\hline Proportion of $\mathrm{SO}_{4}^{2-}, \mathrm{NO}_{3}^{-}, \mathrm{NH}_{4}^{+}$in ionic species & $0.86 \pm 0.06$ & $0.85 \pm 0.06$ & $0.87 \pm 0.07$ & $0.85 \pm 0.07$ & $0.90 \pm 0.09$ \\
\hline Proportion of ionic species in $\mathrm{PM}_{2.5}$ & $0.31 \pm 0.08$ & $0.27 \pm 0.07$ & $0.28 \pm 0.06$ & $0.27 \pm 0.11$ & $0.36 \pm 0.15$ \\
\hline$\left(\mathrm{NH}_{4}^{+}+\mathrm{Ca}^{2+}\right) /\left(\mathrm{SO}_{4}^{2-}+\mathrm{NO}_{3}^{-}\right)(\mu \mathrm{eq} / \mu \mathrm{eq})$ & $0.81 \pm 0.23$ & $0.86 \pm 0.19$ & $0.76 \pm 0.19$ & $0.97 \pm 0.16$ & $1.04 \pm 0.21$ \\
\hline 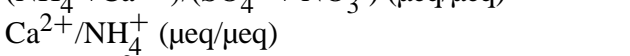 & $0.08 \pm 0.06$ & $0.08 \pm 0.06$ & $0.06 \pm 0.04$ & $0.07 \pm 0.05$ & $0.06 \pm 0.05$ \\
\hline $\mathrm{NO}_{3}^{-} / \mathrm{SO}_{4}^{2-}(\mu \mathrm{eq} / \mu \mathrm{eq})$ & $0.16 \pm 0.08$ & $0.17 \pm 0.08$ & $0.15 \pm 0.07$ & $0.60 \pm 0.32$ & $0.47 \pm 0.28$ \\
\hline
\end{tabular}

however, $\mathrm{NO}_{3}^{-}$and $\mathrm{SO}_{4}^{2-}$ are identified to play different roles in contributing to the acidity of the two cities. As shown in Table $1, \mathrm{NO}_{3}^{-} / \mathrm{SO}_{4}^{2-}$ in $\mathrm{PM}_{2.5}$ in Beijing $(0.47-0.60)$ was $\sim 3-4$ times higher than that in Chongqing (0.15-0.17). This is consistent with the estimated higher contribution from vehicular emissions to $\mathrm{PM}_{2.5}$ in Beijing (Arimoto et al., 1996; Yao et al., 2002). This also agrees with the larger vehicle populations in Beijing (2.1 million) than Chongqing ( 0.47 million) in 2005, where coal consumption was both close to 30 million tons (Beijing Statistic Bureau, 2006; Chongqing Statistic Bureau, 2006). Although $\mathrm{NO}_{3}^{-} / \mathrm{SO}_{4}^{2-}$ may also be influenced by sampling artifacts due to a long sampling duration (Pathak et al., 2004b), the charge ratios were quite close to those previously reported using daily samples for Beijing (0.52 in 2001-2003; Wang et al., 2005) and Chongqing (0.16 in 2003; Aas et al., 2007).

The urban-rural distributions of $\mathrm{R}_{\mathrm{C} / \mathrm{A}}$ for $\mathrm{PM}_{2.5}$ in Beijing and Chongqing were opposite to each other, which can be explained by their compositional difference in $\mathrm{NO}_{3}^{-} / \mathrm{SO}_{4}^{2-}$ and $\mathrm{Ca}^{2+} / \mathrm{NH}_{4}^{+}$. Both of these two ratios were higher at urban sites, possibly due to more vehicle sources and construction activities, however they showed different spatial gradients within the two cities. Compared to the difference of $\mathrm{NO}_{3}^{-} / \mathrm{SO}_{4}^{2-}$ at Chongqing $(<10 \%$; urban: $0.16-$ 0.17 , rural: 0.15 ), the ratio was found $\sim 30 \%$ higher at urban TH (0.60) than rural MY (0.47) at Beijing. At the meantime, $\mathrm{Ca}^{2+} / \mathrm{NH}_{4}^{+}$showed a larger urban-rural difference at Chongqing $(\sim 25 \%)$ than at Beijing $(\sim 10 \%)$. Therefore, it was the higher concentrations of $\mathrm{NO}_{3}^{-}$within the urban site in Beijing and the lower concentrations of $\mathrm{Ca}^{2+}$ within the rural site in Chongqing that made their $\mathrm{PM}_{2.5}$ more acidic. This differs from findings for Pittsburgh where $\mathrm{NH}_{4}^{+}$levels determined the spatial distribution of aerosol acidity at urban and semi-rural sites (Liu et al., 1996).

\subsubsection{Seasonal variation}

The seasonal averages of $\mathrm{R}_{\mathrm{C} / \mathrm{A}}$ of $\mathrm{PM}_{2.5}$ in Beijing and Chongqing are shown in Table 2. In Beijing, $\mathrm{PM}_{2.5}$ at TH was more acidic in the summer of 2005 and spring of 2006 than other seasons $\left(R_{C / A} \leq 1\right.$ for all seasons). Similar seasonal variation in $R_{C / A}$ was also observed at rural $M Y$, but its higher $\mathrm{R}_{\mathrm{C} / \mathrm{A}}$ indicates that $\mathrm{PM}_{2.5}$ was almost neutral in all seasons $\left(R_{C / A} \geq 1\right)$, except for the spring of 2006 $\left(\mathrm{R}_{\mathrm{C} / \mathrm{A}}=0.80\right)$. These results are similar to previous findings that aerosols were more acidic in warm seasons than in cold seasons at Beijing (Wang et al., 2000; Pathak et al., 2009), as indicated from $\mathrm{R}_{\mathrm{C} / \mathrm{A}}$ reproduced from their reported datasets shown in Table 2. However, no consistent pattern in interannual trends can be discerned for each season. During the summer, $\mathrm{R}_{\mathrm{C} / \mathrm{A}}$ was $>1$ in 2001-2003 (Wang et al., 2005) and 2006 (Sun et al., 2010), and $<1$ in 1999-2000 (Wang et al., 2000; He et al., 2001) and 2005 (Pathak et al., 2009; this study); for spring, $\mathrm{R}_{\mathrm{C} / \mathrm{A}}$ was $>1$ in 1994-1995 (Wang et al., 2000) and 2001-2003 (Wang et al., 2005), and $<1$ in 19992000 (He et al., 2001; Dillner et al., 2006) and 2005-2006 (this study); for winter, $\mathrm{R}_{\mathrm{C} / \mathrm{A}}$ was $>1$ in most years except 1999-2000 when it was only 0.63 (He et al., 2001), indicating the aerosols were much more acidic during spring than during other seasons. Similar characteristics in seasonal variation of aerosols are also observed in other northern cities. 
Table 2. Seasonal $\mathrm{R}_{\mathrm{C} / \mathrm{A}}$ at multiple sites in the northern and southern China $\left(\mathrm{R}_{\mathrm{C} / \mathrm{A}}=\left(\mathrm{NH}_{4}^{+}+\mathrm{Ca}^{2+}\right) /\left(\mathrm{SO}_{4}^{2-}+\mathrm{NO}_{3}^{-}\right)(\mu \mathrm{eq} / \mu \mathrm{eq})\right.$, spring $=$ MAM, summer $=\mathrm{JJA}$, fall $=\mathrm{SON}$, winter $=\mathrm{DJF})$.

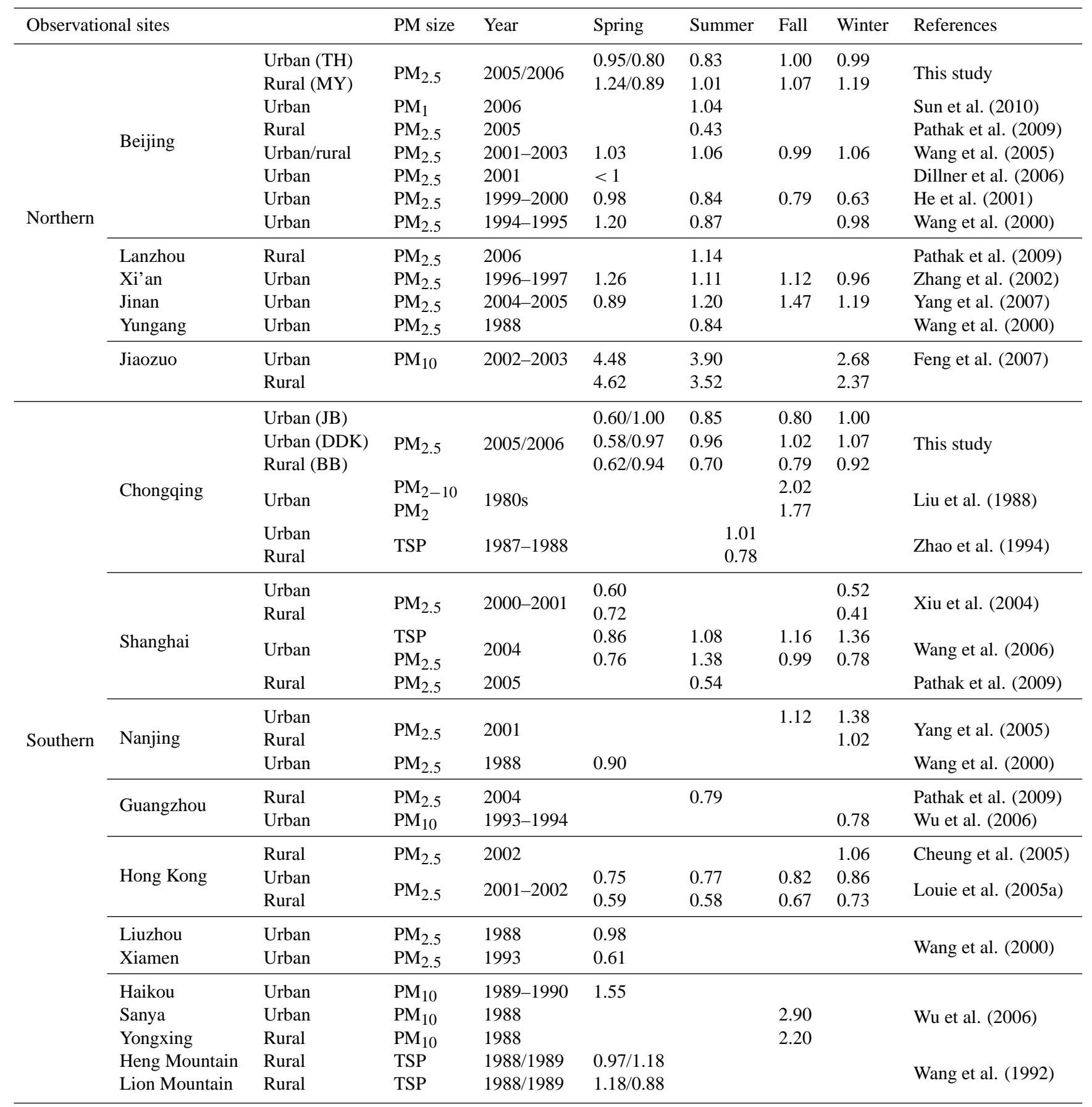

As shown in Table 2, while they were neutralized in most cases $\left(\mathrm{R}_{\mathrm{C} / \mathrm{A}}>1\right)$, very acidic aerosols were also observed at Yungang (summer of 1988; Wang et al., 2000), Xi' an (winter of 1996-1997; Zhang et al., 2002) and Jinan (spring of 2004-2005; Yang et al., 2007).
As in Beijing, $\mathrm{R}_{\mathrm{C} / \mathrm{A}}$ was high in winter and low in summer and fall of 2005 at both urban and rural sites of Chongqing. However, the ratios for the two springs were not the same, with much more acidic aerosols being observed in 2005 $\left(\mathrm{R}_{\mathrm{C} / \mathrm{A}}=0.58-0.62\right)$ than in $2006\left(\mathrm{R}_{\mathrm{C} / \mathrm{A}}=0.94-1.00\right)$. No consistent inter-annual trend in seasonal acidity could be 
found at Chongqing, either. For example, Liu et al. (1988) found $\mathrm{R}_{\mathrm{C} / \mathrm{A}}$ of $\mathrm{PM}_{2}$ to be 1.77 in the fall of $1980 \mathrm{~s}$, much higher than the ratios from our observation (0.79-1.02). The large difference between the two studies cannot be simply explained by the increased acidity of aerosol over the past 20 yr because similarly low $\mathrm{R}_{\mathrm{C} / \mathrm{A}}(0.78-1.01)$ were also measured in TSP by Zhao et al. (1994) during 1987-1988 in Chongqing (the ratio was even lower for fine particles). This phenomenon shifts the likely explanation to factors other than the changes in the emission of acidic aerosols and their precursors. As at Chongqing, aerosol $\mathrm{R}_{\mathrm{C} / \mathrm{A}}$ at other southern cities have also exhibited an inconsistent inter-annual trend in recent years. The $\mathrm{R}_{\mathrm{C} / \mathrm{A}}$ of $\mathrm{PM}_{2.5}$ in Shanghai was significantly higher in the summer and winter of 2004 (1.38 and 0.78 , respectively; Wang et al., 2006) than in summer of 2005 and winter of 2001 (0.4-0.5; Xiu et al., 2004; Pathak et al., 2009), while for Hong Kong the ratio in winter was also distinctively higher in 2002 (1.06; Cheung et al., 2005) than 2001 (0.73; Louie et al., 2005).

In spite of the uncertainties in using $\mathrm{R}_{\mathrm{C} / \mathrm{A}}$ to compare the aerosol acidity between different studies, such as the variable sampling methods, the representativeness of sampling periods, and analytical procedures, the above findings collectively suggest that the seasonal variation of aerosol acidity in northern and southern China may be influenced by a variety of factors (emission strength, meteorological condition and characteristics of preexisting particles and precursors, etc.). For either long-term or short-term field observations, it is consequently risky to attribute the inter-annual changes of aerosol acidity to any of these factors alone. For example, based on a comparison with the acidic aerosols reported by Dillner et al. (2006) for spring 2001, Sun et al. (2010) simply attributed their fully neutralized aerosols in Beijing during the summer of 2006 to the reduced $\mathrm{SO}_{2}$ emissions or increased $\mathrm{NH}_{3}$ emissions in this region.

It is interesting to observe that the inter-annual variation in spring $\mathrm{PM}_{2.5}$ acidity for Chongqing was opposite to that for Beijing. For both cities, their covariation at urban and rural sites indicates that the inter-annual trend was of regional scale. Thus, the weekly $\mathrm{R}_{\mathrm{C} / \mathrm{A}}$ for each city was averaged to investigate the short-period variation in aerosol acidity within each season.

As shown in Fig. 1a, $\mathrm{R}_{\mathrm{C} / \mathrm{A}}$ showed extensive weekly fluctuation for both cities, with larger variation at Beijing (0.39$1.60)$ than at Chongqing (0.51-1.13). However, $\mathrm{R}_{\mathrm{C} / \mathrm{A}}$ at Beijing was higher in the spring of $2005(>1)$ than in $2006(<1$, from the week of 24-31 March), while at Chongqing continuously higher $\mathrm{R}_{\mathrm{C} / \mathrm{A}}$ was observed in the spring of 2006 (0.81.1) than in $2005(0.6-0.8)$. This pattern is better presented as normalized $R_{C / A}\left(R_{C / A}\right.$ minus the averaged ratio during the whole sampling period, as shown in Fig. 1b), indicating a weak intra-seasonal variation of aerosol acidity for both Beijing and Chongqing during the two springs. Also of note is that $\mathrm{R}_{\mathrm{C} / \mathrm{A}}$ at both Beijing and Chongqing showed a similar decreasing trend during February-June 2005 with a sharp in-

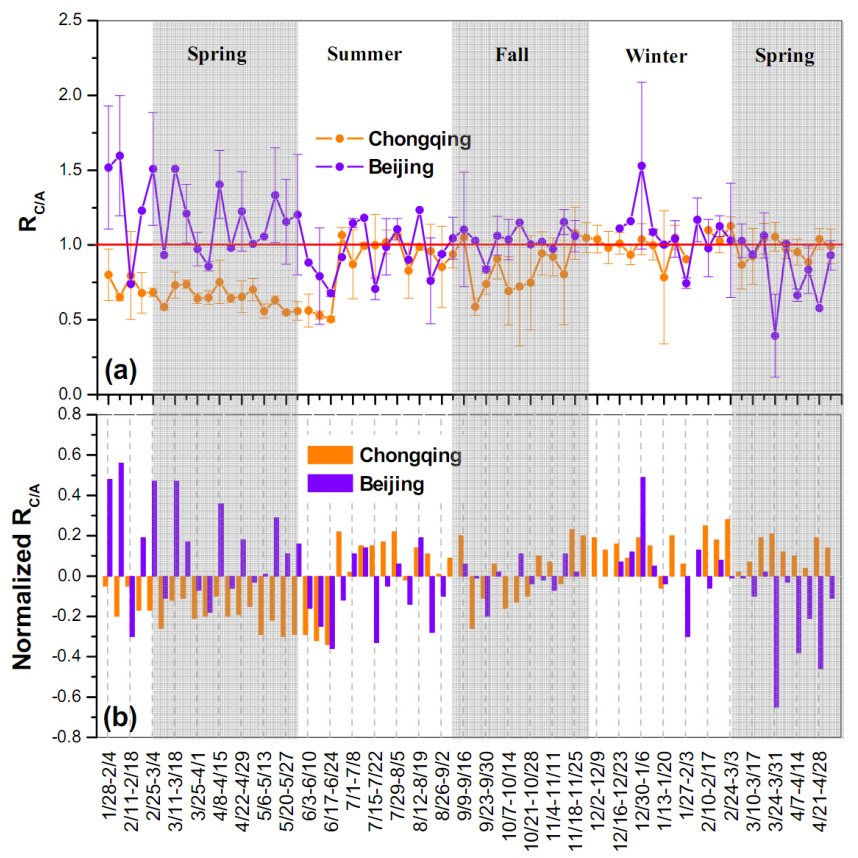

Fig. 1. Seasonal variations of (a) $\mathrm{R}_{\mathrm{C} / \mathrm{A}}$ (uncertainty = standard deviation) and (b) normalized $\mathrm{R}_{\mathrm{C} / \mathrm{A}}$ of $\mathrm{PM}_{2.5}$ at Beijing and Chongqing.

crease at the end, which implies that the aerosol acidity of both cities had been influenced by large-scale driving forces, as discussed in Sect. 4.

\subsection{Seasonal variation of in situ aerosol acidity}

In situ aerosol $\mathrm{pH},\left[\mathrm{H}^{+}\right]_{\text {Ins }}$ and $\left[\mathrm{H}_{2} \mathrm{O}\right]$ of $\mathrm{PM}_{2.5}$ at Beijing and Chongqing were shown in Fig. 2. $\left[\mathrm{NH}_{4}^{+}\right],\left[\mathrm{SO}_{4}^{2-}\right]$ and $\left[\mathrm{NO}_{3}^{-}\right]$were averaged for urban and rural sites and used as the input data to simplify the comparison between the two cities.

The in situ $\mathrm{PM}_{2.5}$ acidity showed similar seasonal variation as previously indicated by $\mathrm{R}_{\mathrm{C} / \mathrm{A}}$, but gave additional insight into the hygroscopic properties of aerosols. As shown in Fig. 2a, it was only in summer and fall of 2005 and spring of 2006 that deliquescent aerosols were found to be abundant at Beijing with free $\mathrm{H}^{+}$, while most of them remained in solid phase during the spring and winter of 2005. The spring of 2006 at Beijing had the most acidic aerosols, with an in situ $\mathrm{pH}$ of only -0.618 to 0.404 , while there were only two weeks in the spring of 2005 when $\mathrm{PM}_{2.5}$ was found acidic. Moreover, although high $\left[\mathrm{H}^{+}\right]_{\text {Ins }}$ existed in $\mathrm{PM}_{2.5}$ during the summer of 2005 (average: $0.030 \mu \mathrm{mol} \mathrm{m}^{-3}$, range: $0.002-0.126 \mu \mathrm{mol} \mathrm{m}^{-3}$ ) and spring of 2006 (average: $0.034 \mu \mathrm{mol} \mathrm{m}^{-3}$, range: $0.006-0.122 \mu \mathrm{mol} \mathrm{m}^{-3}$ ), the former was less acidic because of its much higher $\left[\mathrm{H}_{2} \mathrm{O}\right]$ (average: $3.074 \mu \mathrm{mol} \mathrm{m}^{-3}$, range: $0.100-8.466 \mu \mathrm{mol} \mathrm{m}^{-3}$ ) than the latter (average: $0.186 \mu \mathrm{mol} \mathrm{m}^{-3}$, range: $0.034-$ $\left.0.468 \mu \mathrm{mol} \mathrm{m}^{-3}\right)$. 


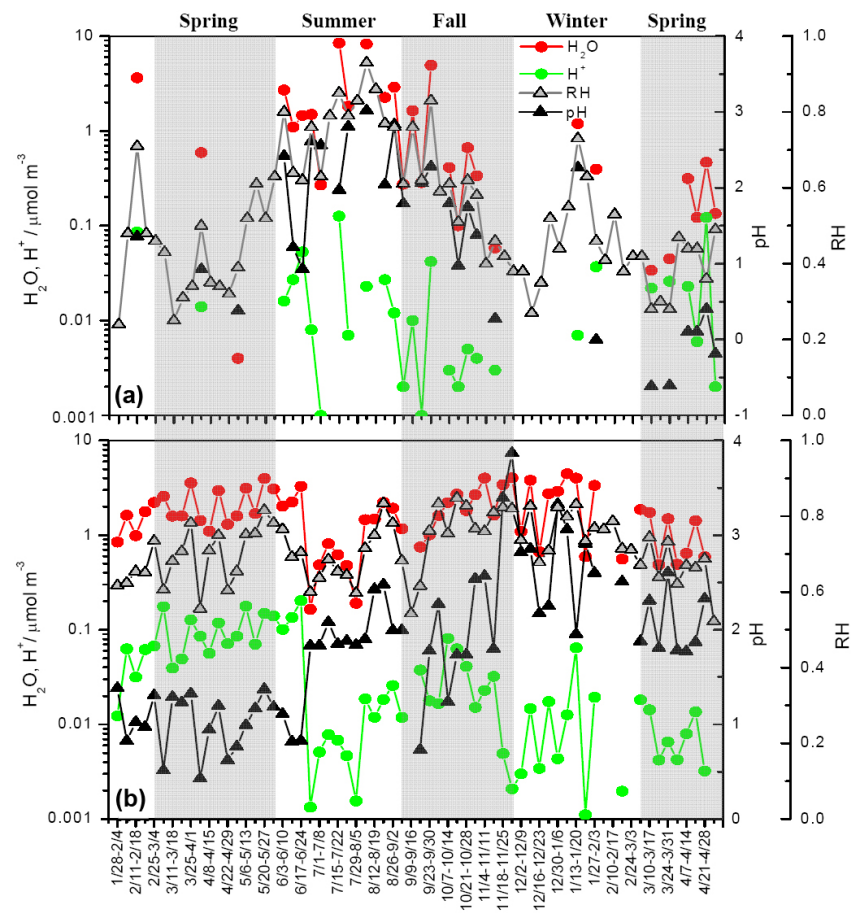

Fig. 2. Seasonal variations of in situ $\mathrm{PM}_{2.5} \mathrm{pH},\left[\mathrm{H}^{+}\right]_{\mathrm{Ins}},\left[\mathrm{H}_{2} \mathrm{O}\right]$ and $\mathrm{RH}$ at (a) Beijing and (b) Chongqing.

Contrasting with Beijing, $\mathrm{PM}_{2.5}$ at Chongqing was deliquescent throughout the year with high $\left[\mathrm{H}^{+}\right]_{\text {Ins }}$ and $\left[\mathrm{H}_{2} \mathrm{O}\right]$, while a significant variation of in situ acidity between the two springs was also clearly evident, as shown in Fig. $2 b$. The most acidic aerosols were found during February-June 2005 , when in situ $\mathrm{pH}$ remained at its lowest level $(0.52-$ 1.38) due to a faster increase in $\left[\mathrm{H}^{+}\right]_{\text {Ins }}$ (20 times) than in $\left[\mathrm{H}_{2} \mathrm{O}\right]$ (5 times). Interestingly, both parameters decreased simultaneously decreased to their lowest level of the whole observation period in the week of 25 June to 1 July 2005, resulting in a significant increase of in situ $\mathrm{pH}$ and thus much less acidic $\mathrm{PM}_{2.5}$. This was also coincident with the week when $\mathrm{R}_{\mathrm{C} / \mathrm{A}}$ showed a remarkable increase (Fig. 1).

In contrast to results revealed by $\mathrm{R}_{\mathrm{C} / \mathrm{A}}$, a noteworthy finding for the variation of in situ $\mathrm{pH}$ is that $\mathrm{PM}_{2.5}$ was more acidic at Beijing than at Chongqing during the springs. This was mainly due to the drier climatology and lower water content in aerosols at Beijing that favored high in situ acidity, even though there might be less free $\mathrm{H}^{+}$. Similar finding was also reported in Hong Kong where variation of in situ $\mathrm{PM}_{2.5}$ acidity was a function of relative humidity $(\mathrm{RH})$ and even the more neutralized particles could have a high acidity under the influence of dry air masses from the Chinese mainland (Pathak et al., 2004a). This result highlighted the importance of the in situ acidity relative to other parameters (Pathak et al., 2004b).

In addition, as one of the most important parameters determining the in situ acidity, $\mathrm{RH}$ clearly exhibited opposite trends from winter into spring at Chongqing during 2005 and 2006, which can partly explain the inter-annual variation of $\mathrm{PM}_{2.5}$ acidity. As shown in Fig. $2 \mathrm{~b}$, for the period from February to May, it increased from $\sim 60$ to $\sim 80 \%$ in 2005 , but decreased from $\sim 80$ to $\sim 50 \%$ in 2006 . These long-playing reverse seasonal trends were likely to have been influenced by large-scale synoptic system anomalies.

\subsection{Factors influencing the spring-summer variation of $\mathbf{P M}_{2.5}$ acidity}

As a case study, we examined in the following the covariation of $\mathrm{PM}_{2.5}$ acidity from spring into summer 2005 for Beijing and Chongqing, as well as the opposite inter-annual variation in $\mathrm{PM}_{2.5}$ acidity in these cities during the springs of 2005 and 2006.

\subsubsection{Asian summer monsoon}

The covariation of $\mathrm{R}_{\mathrm{C} / \mathrm{A}}$ for $\mathrm{PM}_{2.5}$ at Beijing and Chongqing from February to June 2005, with a sharp increase at the end of June, indicates a synoptic-scale influence (Roger and Andrew, 2002).

The anomaly of the Asian summer monsoon in June 2005 was the abnormal behavior of the subtropical high over the Northwestern Pacific (Pacific High, in short) and the trough/ridge systems over mid- and high latitudes (Lu et al., 2007; Mu et al., 2008). The northward movement of the Pacific High, which is one of the most important parameters indicating the evolution of spring into summer in East Asia, was delayed until the end of June 2005. As shown in Fig. 3a (Lu et al., 2007), the ridge of the Pacific High remained around $13-16^{\circ} \mathrm{N}$ before 26 June $2005,3-5^{\circ}$ to the south of the normal position. During 26-28 June, however, it suddenly moved from 17 to $28^{\circ} \mathrm{N}$ at a speed of $3-4^{\circ}$ per day, and its representative positions before and after the movement are indicated by the geopotential heights of $500 \mathrm{hPa}$ in Fig. 3b (23 June) and Fig. 3c (29 June), respectively.

The evolution of air mass sources at Beijing and Chongqing was investigated before and after the northward movement of the Pacific High. The period from 4 March to 27 June 2005 was divided into three phases, including 4 March-6 May (to be compared with the same period in the spring of 2006), 7-31 May and 1-27 June. For each phase, backward trajectories of air masses at $500 \mathrm{~m}$ above ground level of Beijing and Chongqing were classified according to the procedures in Sect. 2.3. Trajectories of longer duration were calculated for Chongqing (120 h) than for Beijing (72 h) because of their different spread of travel.

The increasing aerosol acidity from March to June 2005 in the two cities was closely associated with the contribution of air masses from areas between the Northern China Plain to the south of Beijing and from central China to the east of Chongqing. As shown in Fig. 4, Beijing was gradually dominated by air masses originating from south of the city, which 

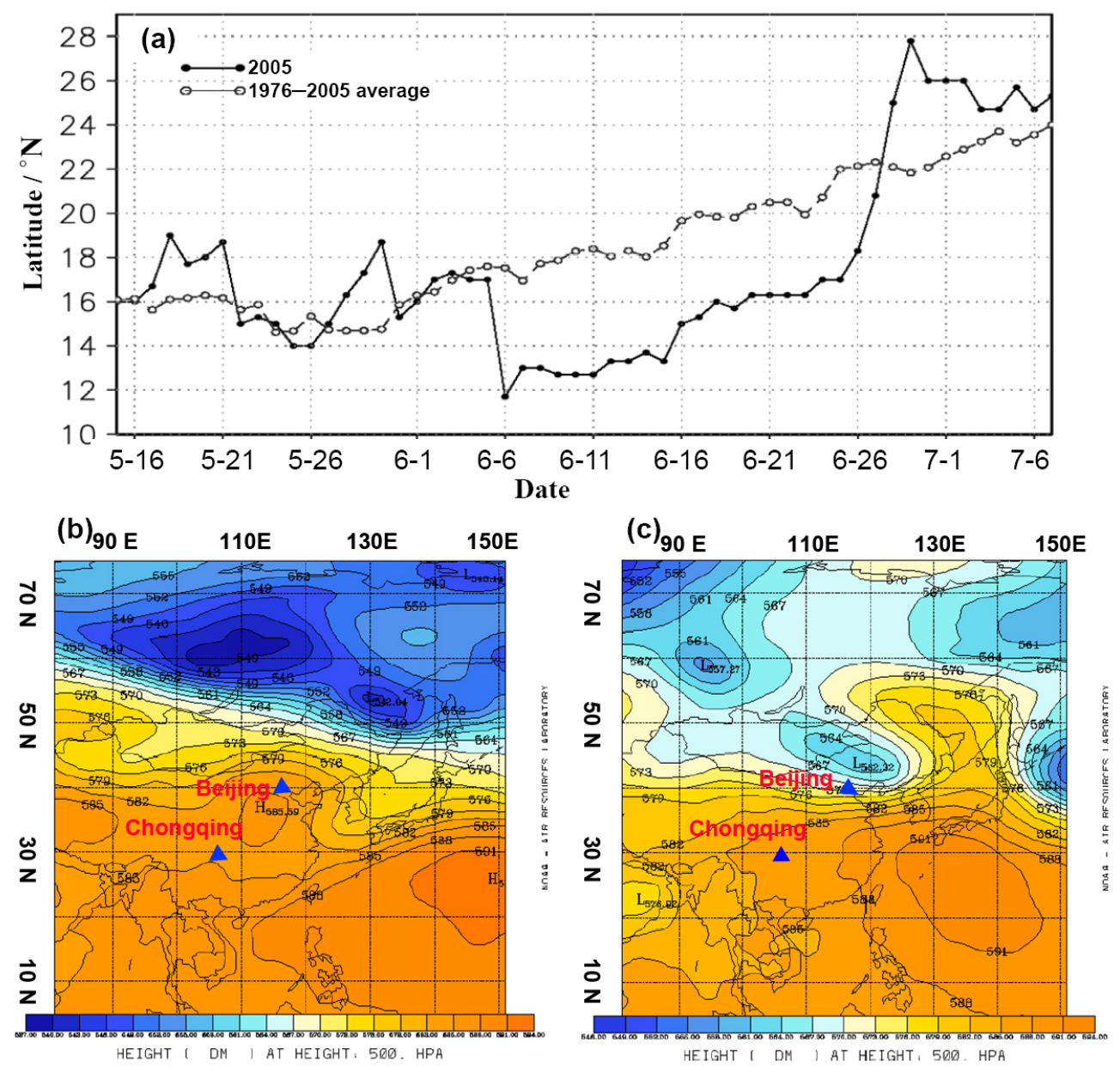

Fig. 3. (a) Daily variation in the subtropical high over the northwestern Pacific between $110-130^{\circ} \mathrm{E}$ (Lu et al., 2007); (b) the geopotential heights of $500 \mathrm{hPa}$ at UTC 08:00, 23 June 2005 over East Asia; (b) the geopotential heights of 500 hPa at UTC 12:00, 29 June 2005 over East Asia.

increased from $13 \%$ in March-April (cluster 5 in Fig. 4a) to $41 \%$ in May (clusters 4 and 5 in Fig. 4c) and $59 \%$ in June (clusters 3 and 4 in Fig. 4d). At the same time, Chongqing was dominated by air masses from the east of the city, which increased from $50 \%$ in March-April (cluster 4 in Fig. 5a) to $65 \%$ in May (clusters 1 and 3 in Fig. 5c) and $73 \%$ in June (clusters 1, 4 and 5 in Fig. 5c). As indicated by the aerosol optical depth (AOD) shown in the Supplement Fig. S1a-c, these source regions were found to have high aerosol loading from March to June in 2005, which clearly suggested that the aerosol acidity was increasing over a broad region of mainland China, with a stronger influence in the south than in the north.

Along with the northward movement of the Pacific High at the end of June 2005, the acidic aerosols over Beijing and Chongqing were replaced by the cleaner air from the northwest and southeast, respectively, which coincided with the simultaneous decrease of $\mathrm{PM}_{2.5}$ acidity at both cities. This effect was also evident from significantly weakened AOD during 29-30 June over a wide region that used to be covered by highly acidic aerosols (Supplement Fig. S1d). In July, Beijing was again dominated by air masses from the south with a monthly contribution (65\% of all air masses) and $\left[\mathrm{H}^{+}\right]_{\text {Ins }}$ level comparable to those in June. However, the Asian summer monsoon was found to have a much greater significance in Chongqing, where the air masses in July were dominated by those having been transported over long distances from the south of China and from southeastern Asia, with high monthly contribution ( $74 \%$ of all air masses), but low aerosol acidity.

These lines of evidence collectively suggest the major role of the Asian summer monsoon in determining the regional evolution of $\mathrm{PM}_{2.5}$ acidity from the spring to the summer of 2005 for Beijing and Chongqing. However, it can not explain the inter-annual variation of $\mathrm{PM}_{2.5}$ acidity during the springs of 2005 and 2006, since no obvious difference was found between the transport patterns of their air mass trajectories. As shown in Figs. $4 \mathrm{~b}$ and 5b, respectively, the dominant air 

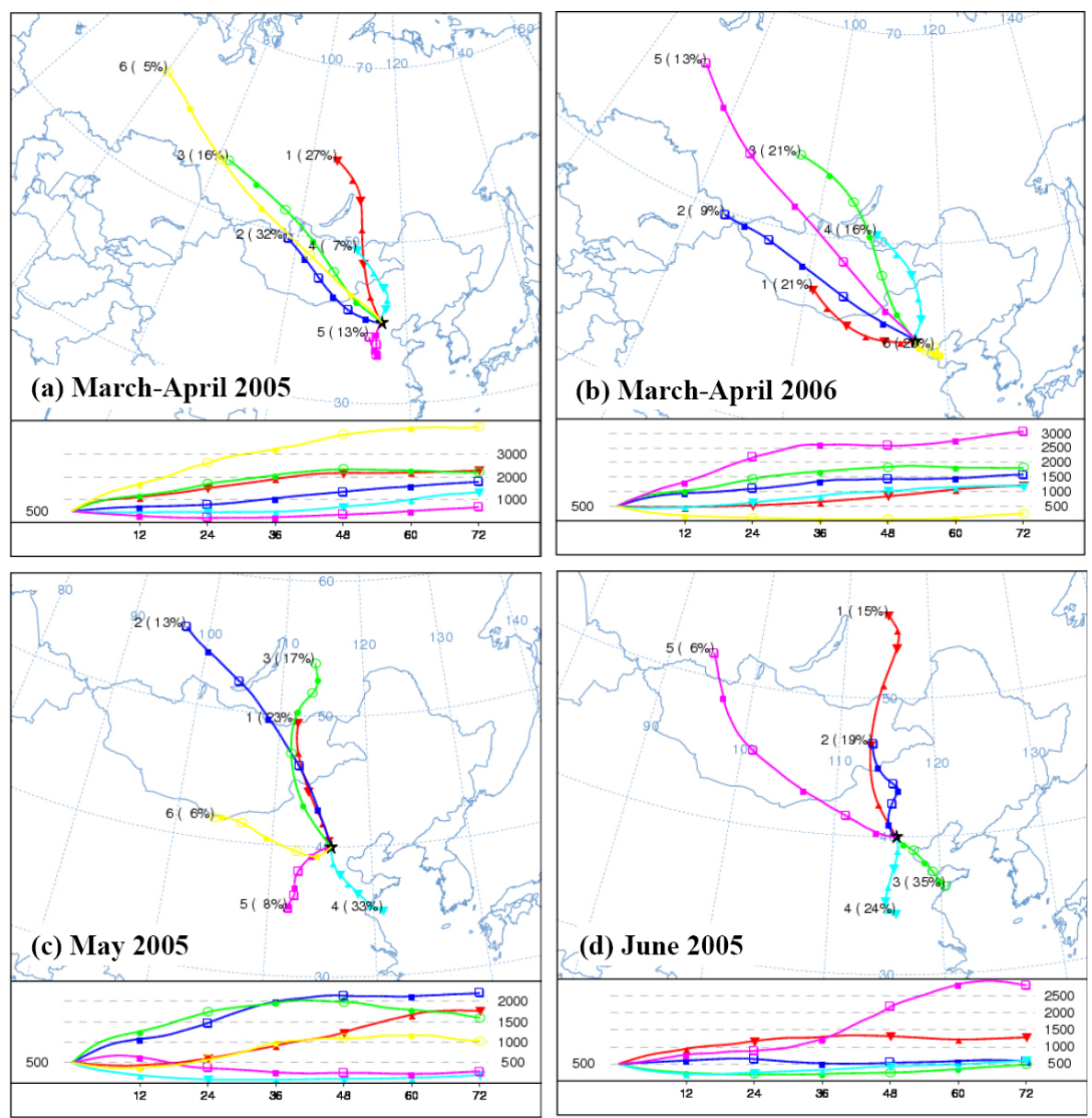

Fig. 4. Clusters of air mass backward trajectories arriving at $500 \mathrm{~m}$ above ground level at Beijing for (a) 4 March-6 May, (c) 7-31 May, (d) 1-27 June in 2005 and (b) 3 March-5 May in 2006.

masses for Beijing and Chongqing from 3 March to 5 May 2006 were also from the northwest and east of China, a situation that was similar to that from 4 March to 6 May 2005 (Figs. 4a and 5a, respectively). Therefore, there must be other factors that caused the inter-annual variation of $\mathrm{PM}_{2.5}$ acidity in the springs of Beijing and Chongqing.

\subsubsection{Asian desert dust}

Mineral dust can affect aerosol acidity by either directly neutralizing the acidic aerosol or increasing the surface area of heterogeneous reaction for the acids. As an indicator of mineral dust, higher $\mathrm{Ca}^{2+}$ as well as higher ratios of $\mathrm{Ca}^{2+} / \mathrm{NH}_{4}^{+}$ were observed in spring of 2005 and 2006 for Chongqing and Beijing, respectively. This is consistent with the findings of Wu et al. (2009) who reported that emission of Asian desert dust was more active in the spring of 2006 than in the spring of 2005 for Beijing, and our related study (Zhao et al., 2010) found Asian dust to be more active in the spring of 2005 than of 2006 for Chongqing.
In order to compare the $\mathrm{R}_{\mathrm{C} / \mathrm{A}}$ and ionic species of the two springs in parallel, data of weekly samples from 4 March to 6 May 2005 and 3 March to 5 May 2006 were averaged to represent the spring of 2005 and 2006 for each site, respectively. As shown in Fig. $6 \mathrm{a}$, the $\mathrm{Ca}^{2+}$ concentration at Beijing was 23.8 to $30.6 \%$ higher in the spring of 2006 than of 2005 , while the concentrations of $\mathrm{SO}_{4}^{2-}$ and $\mathrm{NO}_{3}^{-}$also increased by 11.3 to $23.3 \%$ and 1.9 to $8.8 \%$, respectively, with little variation for $\mathrm{NH}_{4}^{+}$. Due to the small contribution of neutralization from mineral components, the increased $\mathrm{SO}_{4}^{2-}$ and $\mathrm{NO}_{3}^{-}$in the spring of 2006 remained acidic. Meanwhile, a significant increase $(45.5 \%)$ was also found for $\mathrm{NO}_{3}^{-} / \mathrm{SO}_{4}^{2-}$ at urban $\mathrm{TH}$ in the spring of 2006 compared to 2005 , which strongly suggests the influence from enhanced production of $\mathrm{NO}_{3}^{-}$on the surface of mineral particles. It is well known that the reactions with alkaline mineral components are of several magnitudes faster for gaseous $\mathrm{HNO}_{3}$ than for $\mathrm{NO}_{2}$ and $\mathrm{SO}_{2}(\mathrm{Ooki}$ and Uematsu, 2005; Vlasenko et al., 2006), which were all abundant in the atmosphere of Beijing (Bergin et al., 2001). When Asian dust was transported to Beijing, $\mathrm{CaCO}_{3}$ could 

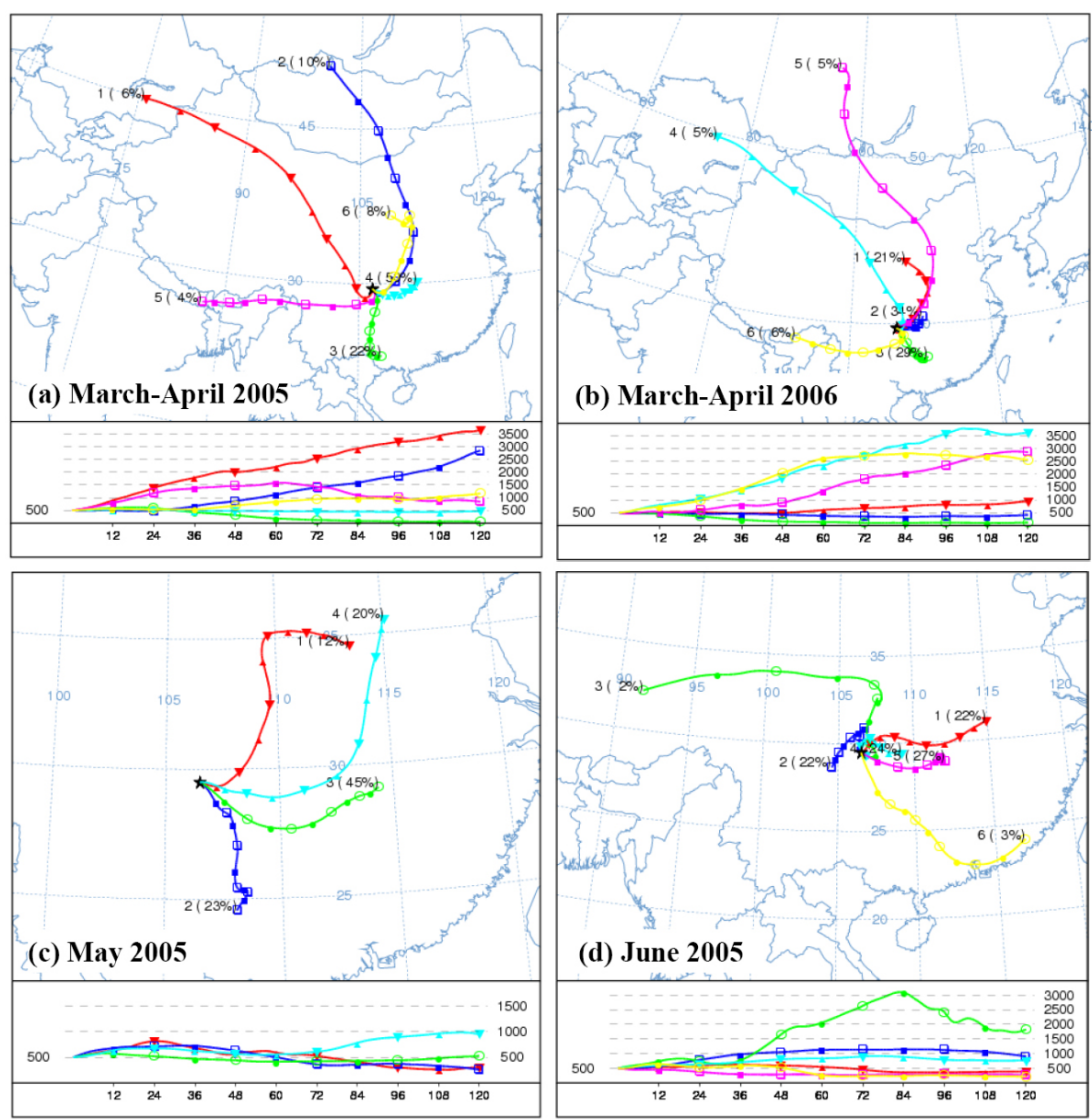

Fig. 5. Clusters of air mass backward trajectories arriving at $500 \mathrm{~m}$ above ground level at Chongqing for (a) 4 March-6 May, (c) 7-31 May, (d) 1-27 June in 2005 and (b) 3 March-5 May in 2006.

react with $\mathrm{HNO}_{3}$ to form $\mathrm{Ca}\left(\mathrm{NO}_{3}\right)_{2}$, providing more hygroscopic surfaces for the heterogeneous reaction with $\mathrm{SO}_{2}$ and $\mathrm{NO}_{2}$, as has been directly observed by single particle analysis during dust storms at Beijing (Li and Shao, 2009). However, $\mathrm{NO}_{3}^{-} / \mathrm{SO}_{4}^{2-}$ showed little increase $(\sim 1.5 \%)$ at $\mathrm{MY}$ in the spring of 2006 compared to 2005, as seen in Fig. 6a. This is perhaps due to the lack of precursors of $\mathrm{NO}_{3}^{-}$, which was more concentrated in urban area of Beijing, and the unstable nature of $\mathrm{NH}_{4} \mathrm{NO}_{3}$, which could easily be decomposed into gaseous $\mathrm{NH}_{3}$ and $\mathrm{HNO}_{3}$ during transport from the urban area to MY.

On the other hand, compared to that in the spring of 2005 a higher increase in $\mathrm{SO}_{4}^{2-}$ was observed at $\mathrm{MY}(23.3 \%)$ than at $\mathrm{TH}(11.3 \%)$ in the spring of 2006. The elevated $\mathrm{SO}_{4}^{2-}$ concentration at the rural MY than at the urban $\mathrm{TH}$ (a pattern not observed for $\mathrm{NO}_{3}^{-}$or $\mathrm{NO}_{3}^{-} / \mathrm{SO}_{4}^{2-}$ ) can be explained by coupling the $\mathrm{SO}_{4}^{2-}$ formation with the inter-annual variation in transport pathways of air masses during spring. Compared to the transport pattern in the spring of 2005 (Fig. 4a), polluted air masses were more frequently transported from the west and south of Beijing in the spring of 2006 (Fig. 4b), which favored a higher regional contribution of $\mathrm{SO}_{4}^{2-}$ at $\mathrm{MY}$ than during periods when other transport pathways were in play (Jia et al., 2008; Zhao et al., 2009). Moreover, faster transformation of local $\mathrm{SO}_{2}$ to $\mathrm{SO}_{4}^{2-}$ at Beijing could also lead to higher increase of $\mathrm{SO}_{4}^{2-}$ in $\mathrm{MY}$ due to the more acidic and hygroscopic aerosols in the southern and southwestern air masses. However, it should be noted that the difference in $\mathrm{NH}_{4}^{+}$concentrations between the two springs was nearly the same for the two sites at Beijing, perhaps because of the recapture of decomposed $\mathrm{NH}_{3}$ from $\mathrm{NH}_{4} \mathrm{NO}_{3}$ by the unneutralized $\mathrm{SO}_{4}^{2-}$ or $\mathrm{HSO}_{4}^{-}$during transport.

Although the influence of Asian dust at Beijing may partly explain the inter-annual variation of $\mathrm{PM}_{2.5}$ acidity for the springs of 2005 and 2006, this does not seem to be an explanatory factor at Chongqing. Firstly, it was a significant decrease in $\mathrm{NH}_{4}^{+}$concentration in the spring of 2005, which was 28.0 to $30.2 \%$ lower than that for the spring of 2006 (Fig. 6b), that essentially led to the elevation of aerosol acidity. The increased concentration of mineral dust might have 

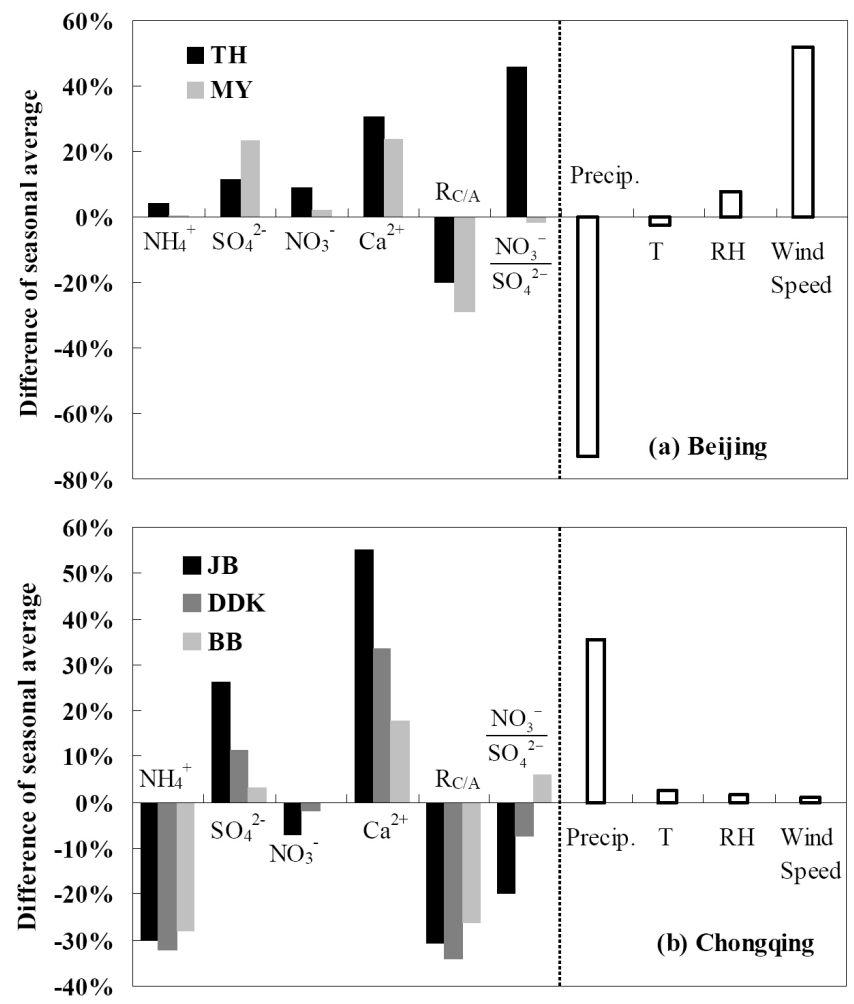

Fig. 6. Differences of $\mathrm{R}_{\mathrm{C} / \mathrm{A}}, \mathrm{NO}_{3}^{-} / \mathrm{SO}_{4}^{2-}$, concentrations of associated ionic species and meteorological factors between the two springs of 2005 and 2006 for (a) Beijing (TH and MY) and (b) Chongqing (JB, DDK and BB), which were calculated based on (2006-2005)/2005 and (2005-2006)/2006, respectively.

changed the gas-particle equilibrium of $\mathrm{NH}_{3} / \mathrm{NH}_{4}^{+}$by limiting the transfer of $\mathrm{NH}_{3}$ to $\mathrm{NH}_{4}^{+}$in fully neutralized aerosols (Luo et al., 2007), but it could hardly influence the highly acidic aerosols at Chongqing during the spring of 2005. Secondly, significant monthly variation in the transport of northwestern air masses was found from March through June 2005 at either the boundary layer (Fig. 5) or the higher atmosphere (Supplement Fig. S2), but the $\mathrm{PM}_{2.5}$ acidity at Chongqing (as indicated by $\mathrm{R}_{\mathrm{C} / \mathrm{A}}$ in Fig. 1 and $\left[\mathrm{H}^{+}\right]_{\text {Ins }}$ in Fig. 2) remained at a consistently high level, and indeed showed a slight increase.

\subsubsection{Wet deposition of $\mathrm{NH}_{4}^{+}$in Chongqing}

Particulate $\mathrm{NH}_{4}^{+}$mainly comes from the gaseous $\mathrm{NH}_{3}$ and has a residence time of 4-6 days compared to only 1 day for gaseous $\mathrm{NH}_{3}$ (Adams et al., 1999). The variation in $\mathrm{NH}_{4}^{+}$ concentration at Chongqing for the two springs can be influenced by many factors, including the emission strength of precursor $\mathrm{NH}_{3}$, the gas-particle equilibrium of $\mathrm{NH}_{3} / \mathrm{NH}_{4}^{+}$, and patterns of atmospheric transport, diffusion and deposition (Asman et al., 1998).
$\mathrm{NH}_{3}$ emissions from natural sources, including animal waste, natural and fertilized soils, and vegetation, usually depend on temperature, which showed little difference between the two springs in Chongqing, as shown in Fig. 6b. Anthropogenic sources, such as industrial process, are considered to be stable during all seasons. The gas-particle equilibrium of $\mathrm{NH}_{3} / \mathrm{NH}_{4}^{+}$is usually related to $\mathrm{NH}_{4} \mathrm{NO}_{3}$ and $\mathrm{NH}_{4} \mathrm{Cl}$, which are unstable; however, these were not the major form of $\mathrm{NH}_{4}^{+}$ in Chongqing due to the high $\mathrm{PM}_{2.5}$ acidity dominated by $\mathrm{SO}_{4}^{2-}$.

The influence of atmospheric transport, diffusion and deposition on $\mathrm{NH}_{4}^{+}$concentration at Chongqing can be assessed from the variation in air mass trajectories and meteorological factors. For the two springs at Chongqing, little difference was observed in the patterns of air mass backward trajectories, as previously discussed. Meanwhile, as shown in Fig. 6b, surface temperature, wind speed and relative humidity also showed weak variations. Together they suggest that atmospheric transport and diffusion at Chongqing play a minor role in explaining the significant inter-annual variation of $\mathrm{NH}_{4}^{+}$during the springs of 2005 and 2006 .

In contrast to all the above factors, the amount of precipitation was $35.5 \%$ higher in the spring of 2005 than of 2006, which is comparable to the differences for $\mathrm{NH}_{4}^{+}$(28.0$30.2 \%)$ and $\mathrm{R}_{\mathrm{C} / \mathrm{A}}(26.3-30.7 \%)$. As shown in Fig. $7 \mathrm{a}$, the precipitation was negatively correlated with $\mathrm{NH}_{4}^{+}$in $\mathrm{PM}_{2.5}$ at the JB site from February 2005 to April $2006(R=-0.63$, $p=0.01$ ), indicating that the wet removal of $\mathrm{NH}_{4}^{+}$was favored by the increase in precipitation. In fact, southwestern China experienced a long drought from the fall of 2005 to the spring of 2006, and the number of days on which rain fell during spring 2005 was 20 to $50 \%$ more than in the spring of 2006 for most cities in the Sichuan Basin (Supplement Fig. S3; meteorological data from http://www. wunderground.com). Although the precipitation in spring at Beijing also showed large inter-annual variation (Fig. 6a), a similar effect of increased precipitation was not evidence due to the much smaller rain volumes during both springs $(40 \mathrm{~mm}$ and $11 \mathrm{~mm}$ in 2005 and 2006, respectively).

Along with these lines of evidence, the chemistry of wet deposition at Chongqing, derived from the Acid Deposition Monitoring Network in East Asia (http://www.eanet.cc/ product/index.html), also suggests the significant influence of precipitation on the variation of $\mathrm{NH}_{4}^{+}$in $\mathrm{PM}_{2.5}$. Since $\mathrm{NH}_{4}^{+}$and $\mathrm{SO}_{4}^{2-}$ were the major species determining $\mathrm{PM}_{2.5}$ acidity at Chongqing, the ratio of $\mathrm{NH}_{4}^{+} / \mathrm{SO}_{4}^{2-}$ (eq/eq) was used to better present the chemical behavior of $\mathrm{NH}_{4}^{+}$in determining the acidity of $\mathrm{PM}_{2.5}$ and precipitation. As shown in Fig. 7b, during February-November 2005 when precipitation was relatively abundant, the ratios of $\mathrm{NH}_{4}^{+} / \mathrm{SO}_{4}^{2-}$ in the precipitation and $\mathrm{PM}_{2.5}$ were significantly negatively correlated with each other at Chongqing $(R=-0.88, p<0.001)$. However, only a weak correlation $(R=0.44, p=0.38)$ was found for the dry seasons from November 2005 to April 

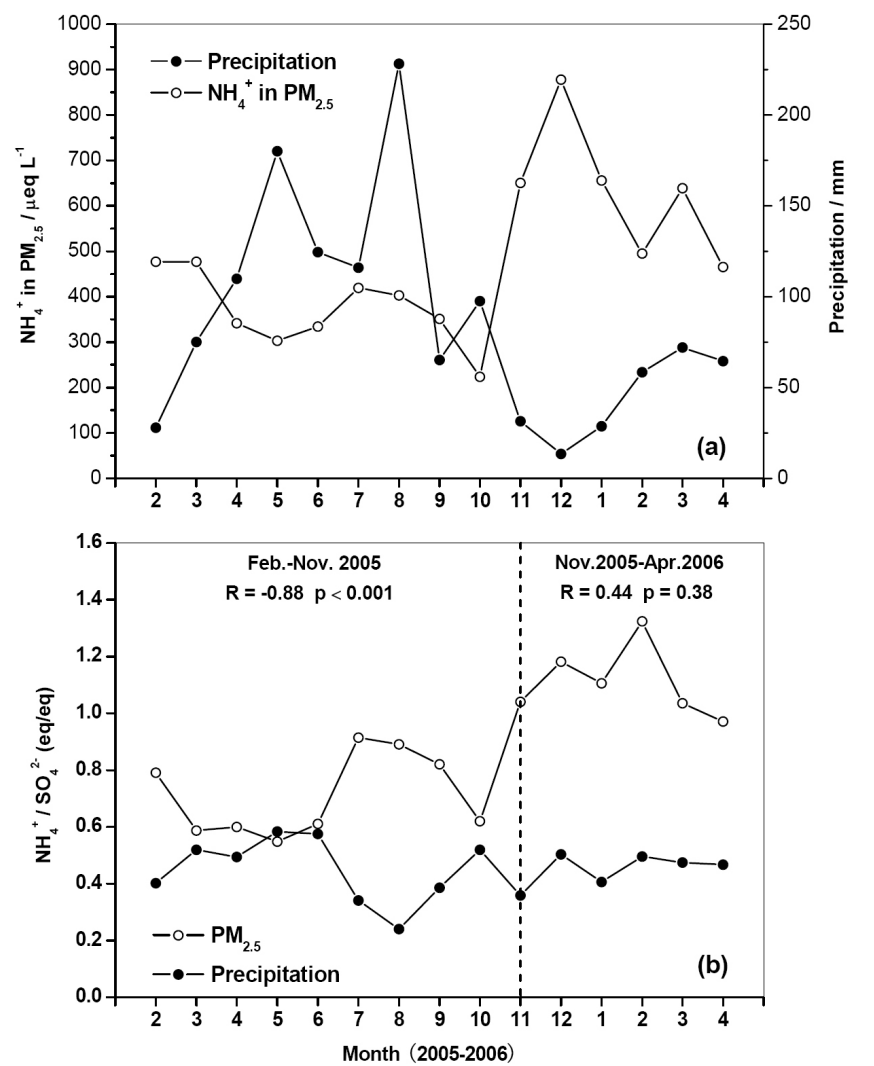

Fig. 7. Monthly variations of (a) amount of precipitation vs. concentration of $\mathrm{NH}_{4}^{+}$in $\mathrm{PM}_{2.5}$ and (b) equivalent charge ratios of $\mathrm{NH}_{4}^{+} / \mathrm{SO}_{4}^{2-}$ in $\mathrm{PM}_{2.5}$ vs. precipitation at Chongqing from February 2005 to April 2006.

2006, possibly due to the fact that the two datasets became less suitable for comparison as the period covered by the rain samples was much shorter than that of the $\mathrm{PM}_{2.5}$ samples.

Interestingly, the influence of the Asian summer monsoon on wet deposition of $\mathrm{NH}_{4}^{+}$is also evident in Fig. 7b. The ratio of $\mathrm{NH}_{4}^{+} / \mathrm{SO}_{4}^{2-}$ increased from February to June in 2005, decreased and remained at a low level after the arrival of the prevailing summer monsoon in July, and returned to a higher level in October when the winter monsoon started to prevail. All of these collectively suggest that precipitation was one of the key factors that dominated the partition of $\mathrm{NH}_{4}^{+}$in $\mathrm{PM}_{2.5}$ and rain water at Chongqing, and the enhanced wet deposition of $\mathrm{NH}_{4}^{+}$was responsible for the lower $\mathrm{NH}_{4}^{+}$and higher acidity of $\mathrm{PM}_{2.5}$ during the spring of 2005 compared to that of 2006. Our findings have important implications for the interpretation of large-scale variability of airborne $\mathrm{NH}_{3} / \mathrm{NH}_{4}^{+}$. For example, large inter-annual variation of $\mathrm{NH}_{3}$ was recently observed at a rural site in southwestern China, the cause of which remained undetermined (Meng et al., 2010).

\subsection{Formation of $\mathrm{NO}_{3}^{-}$at different levels of aerosol acidity}

As $\mathrm{SO}_{4}^{2-}$ competes with $\mathrm{NO}_{3}^{-}$for $\mathrm{NH}_{4}^{+}$during its formation, the relationship between $\mathrm{NO}_{3}^{-}$and $\mathrm{NH}_{4}^{+}$at different levels of $\mathrm{SO}_{4}^{2-}$, which are expressed as $\left[\mathrm{NO}_{3}^{-}\right] /\left[\mathrm{SO}_{4}^{2-}\right]$ and $\left[\mathrm{NH}_{4}^{+}\right] /\left[\mathrm{SO}_{4}^{2-}\right]$, is indicative of the pathway of $\mathrm{NO}_{3}^{-}$formation (Pathak et al., 2004a, 2009). For a variety of cities worldwide, linear correlation between $\left[\mathrm{NO}_{3}^{-}\right] /\left[\mathrm{SO}_{4}^{2-}\right]$ and $\left[\mathrm{NH}_{4}^{+}\right] /\left[\mathrm{SO}_{4}^{2-}\right]$ in $\mathrm{NH}_{4}^{+}$-rich conditions $\left(\left[\mathrm{NH}_{4}^{+}\right] /\left[\mathrm{SO}_{4}^{2-}\right] \geq 1.5\right.$, molar ratio) suggested the homogenous formation of $\mathrm{NO}_{3}^{-}$:

$\mathrm{HNO}_{3}(\mathrm{~g})+\mathrm{NH}_{3}(\mathrm{~g}) \rightleftarrows \mathrm{NH}_{4} \mathrm{NO}_{3}(\mathrm{~s}, \mathrm{aq})$

while no relationship was observed in $\mathrm{NH}_{4}^{+}$-poor conditions $\left(\left[\mathrm{NH}_{4}^{+}\right] /\left[\mathrm{SO}_{4}^{2-}\right]<1.5\right)$ and the high level of $\mathrm{NO}_{3}^{-}$was attributed to its formation from the hydrolysis of $\mathrm{N}_{2} \mathrm{O}_{5}$ on the preexisting aerosols (Pathak et al., 2009):

$\mathrm{N}_{2} \mathrm{O}_{5}(\mathrm{aq})+\mathrm{H}_{2} \mathrm{O}(\mathrm{aq}) \rightleftarrows 2 \mathrm{NO}_{3}^{-}(\mathrm{aq})+2 \mathrm{H}^{+}(\mathrm{aq})$

However, our study found significant correlations between $\left[\mathrm{NO}_{3}^{-}\right] /\left[\mathrm{SO}_{4}^{2-}\right]$ and $\left[\mathrm{NH}_{4}^{+}\right] /\left[\mathrm{SO}_{4}^{2-}\right]$ during both $\mathrm{NH}_{4}^{+}$-rich and $\mathrm{NH}_{4}^{+}$-poor conditions at Beijing and Chongqing. Thus aerosol acidity, in terms of the ratio $\mathrm{R}_{\mathrm{C} / \mathrm{A}}$, was used instead as the key parameter to investigate the relationship between $\left[\mathrm{NO}_{3}^{-}\right] /\left[\mathrm{SO}_{4}^{2-}\right]$ and $\left[\mathrm{NH}_{4}^{+}\right] /\left[\mathrm{SO}_{4}^{2-}\right]$, as well as the formation pathways of $\mathrm{NO}_{3}^{-}$. Considering the uncertainties in representing the neutralization level of $\mathrm{PM}_{2.5}$, a $\mathrm{R}_{\mathrm{C} / \mathrm{A}}$ ratio of 0.9 was used to divide the samples into a group of more acidic aerosols $\left(\mathrm{R}_{\mathrm{C} / \mathrm{A}}<0.9\right)$ and a group of less acidic aerosols $\left(R_{C / A} \geq 0.9\right)$, which gave the prospect of a good fit in the regression analysis as discussed below.

$\left[\mathrm{NO}_{3}^{-}\right] /\left[\mathrm{SO}_{4}^{2-}\right]$ is plotted against $\left[\mathrm{NH}_{4}^{+}\right] /\left[\mathrm{SO}_{4}^{2-}\right]$ at different acidities for both Beijing and Chongqing $\mathrm{PM}_{2.5}$ in Fig. 8a. For less acidic samples $\left(\mathrm{R}_{\mathrm{C} / \mathrm{A}} \geq 0.9\right)$, although their $\left[\mathrm{NO}_{3}^{-}\right] /\left[\mathrm{SO}_{4}^{2-}\right]$ showed a clear intercity variation, with higher ratios at Beijing $(\geq 0.6)$ than at Chongqing $(\leq 0.6)$, together they were significantly correlated with $\left[\mathrm{NH}_{4}^{+}\right] /\left[\mathrm{SO}_{4}^{2-}\right]$ $\left(R^{2}=0.71, p<0.001\right)$ with the regression function:

$\frac{\left[\mathrm{NO}_{3}^{-}\right]}{\left[\mathrm{SO}_{4}^{2-}\right]}=0.80 \times \frac{\left[\mathrm{NH}_{4}^{+}\right]}{\left[\mathrm{SO}_{4}^{2-}\right]}-1.33$

The intercept of the regression line with the axis of $\left[\mathrm{NH}_{4}^{+}\right] /\left[\mathrm{SO}_{4}^{2-}\right]$ (1.66) was close to that (1.5) found by Pathak et al. (2009), indicating that $\mathrm{NO}_{3}^{-}$in these less acidic samples was mainly formed from Eq. (4) between $\mathrm{HNO}_{3}$ and the excess $\mathrm{NH}_{3}$, which became available after neutralizing most of the $\mathrm{SO}_{4}^{2-}$ and $\mathrm{HSO}_{4}^{-}$. Excess $\mathrm{NH}_{4}^{+}$associated with the formation of $\mathrm{NO}_{3}^{-}$can be derived from the following equation:

$\left[\mathrm{NH}_{4}^{+}\right]_{\text {Excess }}=\left(\frac{\left[\mathrm{NH}_{4}^{+}\right]}{\left[\mathrm{SO}_{4}^{2-}\right]}-1.66\right) \times\left[\mathrm{SO}_{4}^{2-}\right]$ 

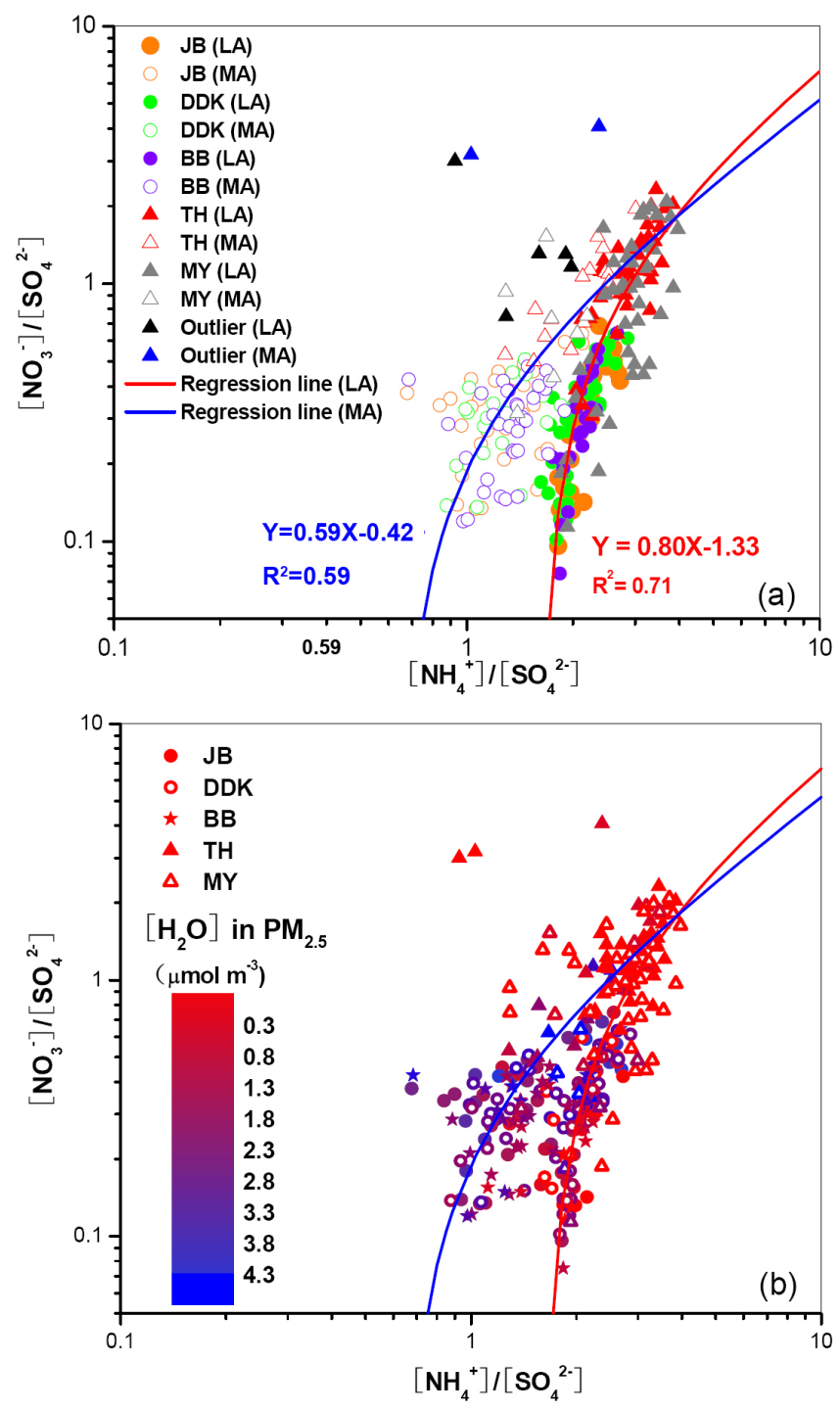

Fig. 8. Molar ratios of $\left[\mathrm{NO}_{3}^{-}\right] /\left[\mathrm{SO}_{4}^{2-}\right]$ vs. $\left[\mathrm{NH}_{4}^{+}\right] /\left[\mathrm{SO}_{4}^{2-}\right]$ at different (a) acidity and (b) water content $\left(\left[\mathrm{H}_{2} \mathrm{O}\right]\right)$ in $\mathrm{PM}_{2.5}$ at Beijing (TH and MY) and Chongqing (JB, DDK and BB). LA, less acidic. MA, more acidic.

For both Beijing and Chongqing, significant correlation $\left(R^{2}=0.70, p<0.001\right)$ was found between the excess $\mathrm{NH}_{4}^{+}$ and $\mathrm{NO}_{3}^{-}$when $\left[\mathrm{NH}_{4}^{+}\right]$Excess $\geq 30 \mathrm{nmol} \mathrm{m}^{-3}$ (Fig. 9). The slope of regression line for $\mathrm{NO}_{3}^{-}$against excess $\mathrm{NH}_{4}^{+}$at Beijing equaled to 1.0 , which is consistent with the molar ratio for the reaction between $\mathrm{HNO}_{3}$ and $\mathrm{NH}_{3}$. However, a shallower slope (0.65) was found for Chongqing, which indicates that in $\mathrm{PM}_{2.5}$ there was approximately $35 \%$ excess $\mathrm{NH}_{4}^{+}$bounded to species other than $\mathrm{NO}_{3}^{-}$. Some of which might exist in the form of $\mathrm{NH}_{4} \mathrm{Cl}$, while others could be associated with acidic $\mathrm{SO}_{4}^{2-}$ or $\mathrm{HSO}_{4}^{-}$, which could recapture the decomposed $\mathrm{NH}_{3}$ from $\mathrm{NH}_{4} \mathrm{NO}_{3}$, as shown by the following equation:

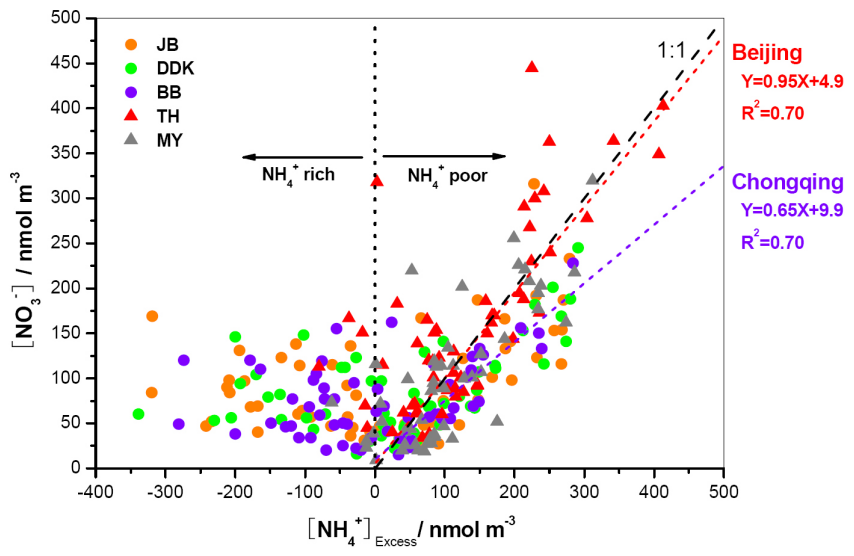

Fig. 9. Relationships between molar concentrations of $\left[\mathrm{NO}_{3}^{-}\right]$and $\left[\mathrm{NH}_{4}^{+}\right]_{\text {Excess }}$ in $\mathrm{PM}_{2.5}$ at Beijing (TH and MY) and Chongqing (JB, DDK and BB).

$\mathrm{NH}_{4} \mathrm{NO}_{3}(\mathrm{~s}, \mathrm{aq})+\mathrm{H}^{+}(\mathrm{aq}) \rightleftarrows \mathrm{HNO}_{3}(\mathrm{~g}, \mathrm{aq})+\mathrm{NH}_{4}^{+}(\mathrm{aq})$

For the more acidic samples $\left(\mathrm{R}_{\mathrm{C} / \mathrm{A}}<0.9\right)$, a significant correlation $\left(R^{2}=0.59, p<0.001\right)$ also existed between $\left[\mathrm{NO}_{3}^{-}\right] /\left[\mathrm{SO}_{4}^{2-}\right]$ and $\left[\mathrm{NH}_{4}^{+}\right] /\left[\mathrm{SO}_{4}^{2-}\right]$, although $R^{2}$ was slightly lower than that of the less acidic samples. Its regression equation was:

$\frac{\left[\mathrm{NO}_{3}^{-}\right]}{\left[\mathrm{SO}_{4}^{2-}\right]}=0.59 \times \frac{\left[\mathrm{NH}_{4}^{+}\right]}{\left[\mathrm{SO}_{4}^{2-}\right]}-0.42$

Its intercept with the axis of $\left[\mathrm{NH}_{4}^{+}\right] /\left[\mathrm{SO}_{4}^{2-}\right](0.71)$ was much smaller than that for the less acidic samples (1.66). However it is notable that the two lines approximated each other as $\left[\mathrm{NH}_{4}^{+}\right] /\left[\mathrm{SO}_{4}^{2-}\right]$ increased over 1.66 , indicating that the homogeneous reaction for $\mathrm{HNO}_{3}$ and $\mathrm{NH}_{3}$ was also favored with abundant $\mathrm{NH}_{4}$ in the acidic samples. On the other hand, along with decreasing $\left[\mathrm{NH}_{4}^{+}\right] /\left[\mathrm{SO}_{4}^{2-}\right]$, a large $\mathrm{NH}_{4}^{+}$deficit $\left(\left[\mathrm{NH}_{4}^{+}\right]_{\text {Excess }}\right.$ of up to $-350 \mathrm{nmol} \mathrm{m}^{-3}$, calculated according to Eq. 7) was evident in these more acidic samples (Fig. 9), and the reaction of Eq. (4) was supposed to be constrained. However, markedly high concentrations of $\mathrm{NO}_{3}^{-}$were still found at Chongqing (up to $169 \mathrm{nmol} \mathrm{m}^{-3}$ ) and Beijing (up to $318 \mathrm{nmol} \mathrm{m}^{-3}$ ), which suggests the dominance of heterogeneous reactions without involving $\mathrm{NH}_{3}$, most likely the hydrolysis of $\mathrm{N}_{2} \mathrm{O}_{5}$ on the preexisting aerosols (Pathak et al., 2009).

The close correlation between $\left[\mathrm{NO}_{3}^{-}\right] /\left[\mathrm{SO}_{4}^{2-}\right]$ and $\left[\mathrm{NH}_{4}^{+}\right] /\left[\mathrm{SO}_{4}^{2-}\right]$ for the more acidic aerosols (which is in contrast to the weak correlation reported by Pathak et al., 2009) can be explained in at least two ways. Firstly, due to the long sampling duration of our study $\left(\sim 1\right.$ week), $\mathrm{NO}_{3}^{-}$in each sample had formed from both homogenous and heterogeneous reactions, and thus a good correlation between $\left[\mathrm{NO}_{3}^{-}\right] /\left[\mathrm{SO}_{4}^{2-}\right]$ and $\left[\mathrm{NH}_{4}^{+}\right] /\left[\mathrm{SO}_{4}^{2-}\right]$ might exist even for those dominated by the latter pathway. Secondly, with an increase 
in aerosol acidity and a decrease in $\left[\mathrm{NH}_{4}^{+}\right] /\left[\mathrm{SO}_{4}^{2-}\right], \mathrm{NO}_{3}^{-}$ tends to partition into coarse particles with abundant alkaline mineral components (Pakkanen et al., 1996; Zhuang et al., 1999). Consequently there is a decrease in $\left[\mathrm{NO}_{3}^{-}\right] /\left[\mathrm{SO}_{4}^{2-}\right]$ that is positively correlated with $\left[\mathrm{NH}_{4}^{+}\right] /\left[\mathrm{SO}_{4}^{2-}\right]$ in fine particles (Sun et al., 2006).

These hypotheses are further suggested by coupling the variation of aerosol water content with the two compositional ratios. As shown in Fig. 8b, aerosol samples with $\left[\mathrm{NH}_{4}^{+}\right] /\left[\mathrm{SO}_{4}^{2-}\right]<1.66$ contained more water, indicating the vital role of the liquid phase reactions of Eq. (5), while less water was observed in most of the other samples $\left(\left[\mathrm{NH}_{4}^{+}\right] /\left[\mathrm{SO}_{4}^{2-}\right] \geq 1.66\right)$, in which $\mathrm{NO}_{3}^{-}$formation was dominated by the gaseous reaction of Eq. (1). However, relatively high water content was also found in some of the less acidic samples with high $\left[\mathrm{NH}_{4}^{+}\right] /\left[\mathrm{SO}_{4}^{2-}\right]$, which were mainly collected during the winter in Chongqing and the summer in Beijing. $\mathrm{NO}_{3}^{-}$in these samples may be formed on the existing particles and/or to in-cloud processes as $\mathrm{NH}_{4} \mathrm{NO}_{3}$ (Yao et al., 2003).

It should be noted that there were, respectively, 5 and 2 outliers excluded in the regression analysis of $\left[\mathrm{NO}_{3}^{-}\right] /\left[\mathrm{SO}_{4}^{2-}\right]$ against $\left[\mathrm{NH}_{4}^{+}\right] /\left[\mathrm{SO}_{4}^{2-}\right]$ for the less acidic and the more acidic samples, as shown in Fig. 8a. These outliers, all collected during spring and winter in Beijing, were found to have significantly higher $\left[\mathrm{Ca}^{2+}\right] /\left[\mathrm{NH}_{4}^{+}\right]$than other samples with low water content (Fig. 8b), which suggests that heterogeneous reactions on the dry surface of fine mineral particles was also an important pathway during these periods at Beijing.

\section{Conclusions and atmospheric implications}

The spatial and seasonal variations of $\mathrm{PM}_{2.5}$ acidity were investigated at both rural and urban sites of Beijing and Chongqing from January 2005 to May 2006. With similar levels of $\mathrm{NH}_{4}^{+}$at each site, $\mathrm{PM}_{2.5}$ was generally more acidic at Chongqing than at Beijing. $\mathrm{SO}_{4}^{2-}$ concentrations in $\mathrm{PM}_{2.5}$ was higher in Chongqing but lower in Beijing, indicating a more important contribution to $\mathrm{PM}_{2.5}$ from coal combustion in southwestern China and more influence to $\mathrm{PM}_{2.5}$ from vehicular emissions in Beijing. The intra-city comparison of $\mathrm{PM}_{2.5}$ acidity showed a reverse pattern for Beijing and Chongqing, with higher levels of $\mathrm{NO}_{3}^{-}$and lower levels of $\mathrm{Ca}^{2+}$ making $\mathrm{PM}_{2.5}$ more acidic in urban areas of Beijing and in rural areas of Chongqing.

$\mathrm{PM}_{2.5}$ was more acidic in the summer and fall than in winter of 2005 at Beijing and Chongqing, but large inter-annual variation was found during the springs of 2005 and 2006, with two cities exhibiting opposite trends. The higher acidity of $\mathrm{PM}_{2.5}$ in the spring of 2006 at Beijing was attributed to the influence of Asian desert dust with significant enhancement of the formation of $\mathrm{NO}_{3}^{-}$relative to $\mathrm{SO}_{4}^{2-}$, both of which were not completely neutralized by the increase in alkaline dust, however. For Chongqing, the higher acidity of $\mathrm{PM}_{2.5}$ in the spring of 2005 was mainly due to increased wet deposition of $\mathrm{NH}_{4}^{+}$. As revealed by a variety of previous studies, significant inter-annual variation in aerosol acidity was also found during other seasons at Beijing, Chongqing and many other cities in China, with no consistent long-term trend. These variations may be influenced by a variety of factors, such as emission strength, meteorological conditions and the characteristics of preexisting particles and precursors.

The Asian monsoon systems were found to be related to the synoptic-scale evolution of $\mathrm{PM}_{2.5}$ acidity at Beijing and Chongqing from spring to early summer in 2005. For both cities, $\mathrm{PM}_{2.5}$ acidity increased from spring to early summer of 2005, a trend that was closely associated with an increased contribution of air masses from between the Northern China Plain to the south of Beijing and from central China to the east of Chongqing. The regionally acidic aerosols were replaced by more neutralized aerosols at the end of June 2005, coupled with the northward movement of a subtropical high over the northwestern Pacific, which is a major element of the Asian summer monsoon. Previous studies have found a seasonal influence of the Asian monsoon on the concentrations of aerosol and gaseous pollutants in China (e.g. He et al., 2001; Ye et al., 2003; Wai and Turner, 2005; Xin et al., 2007; Zhang et al., 2010), but few of them, if any, have related its behavior to large-scale variability in aerosol acidity. Moreover, a recent study using modeling suggests that the strength of the Asian monsoon could influence the inter-annual variation in aerosols in eastern China mostly by altering wet deposition and aerosol transport (Zhang et al., 2010), which we believe is also likely to explain the inter-annual variation of aerosol acidity during the springs of 2005 and 2006. For example, $\mathrm{RH}$, one of most important parameters influencing in situ aerosol acidity, exhibited opposite trends from winter into spring at Chongqing during 2005 and 2006, a situation that was likely influenced by large-scale synoptic system anomalies. In the meantime, more air masses from northwestern Asian deserts were transported to the south of the country in the spring of 2005 than of 2006, while the reverse trend was found for the air masses influencing the Northern China Plain (not shown). This may also have been related to variation of the strength of the Asian monsoon, which was found to have greater bearing on the transport pathway of dust to the Asian subcontinent than to dust production itself (Gong et al., 2006). Clearly, these are important subjects of future work.

$\mathrm{PM}_{2.5}$ acidity was closely related to the formation of $\mathrm{NO}_{3}^{-}$ at both Beijing and Chongqing. $\mathrm{NO}_{3}^{-}$formation in more neutralized $\mathrm{PM}_{2.5}$ was favored by the homogeneous reaction of $\mathrm{HNO}_{3}$ and $\mathrm{NH}_{3}$, while heterogeneous reactions (such as the hydrolysis of $\mathrm{N}_{2} \mathrm{O}_{5}$ on preexisting aerosols with higher water content) may become major pathways when particulates are more acidic. In addition, the formation of $\mathrm{NO}_{3}^{-}$on the relatively dry surface of mineral dust could also be an important pathway during winter and spring at Beijing. 
Aerosol acidity has also frequently been linked to the formation of secondary organic aerosols (Jang et al., 2002; Takahama et al., 2006; Zhang et al., 2007a). In addition to the inorganic aerosols discussed in this study, we also observed significantly higher ratios of Organic carbon to Elemental carbon (OC/EC) in the spring of 2005 than of 2006 at the rural sites of both Beijing and Chongqing (unpublished data); a pattern which was not in evidence at the urban sites, however. This phenomenon probably indicates the different levels of oxidation of organic aerosols in the background air masses, and more detailed investigation is required.

\section{Supplementary material related to this article is available online at: http://www.atmos-chem-phys.net/12/1377/2012/ acp-12-1377-2012-supplement.pdf.}

Acknowledgements. This research was supported by the National Natural Science Foundation of China (20625722). We would like to thank Yingtao Jia, Yuan Cheng and the staff of the Chongqing Research Academy of Environmental Sciences for their help in sample collection and chemical analysis. We also gratefully acknowledge the NOAA Air Resources Laboratory (ARL) for provision of the HYSPLIT trajectory model and meteorological data, and Simon Clegg, Peter Brimblecombe and Anthony Wexler for sharing the E-AIM model.

Edited by: X. Tie

\section{References}

Aas, W., Shao, M., Jin, L., Larssen, T., Zhao, D. W., Xiang, R. J., Zhang, J. H., Xiao, J. S., and Duan, L.: Air concentrations and wet deposition of major inorganic ions at five non-urban sites in China, 2001-2003, Atmos. Environ., 41, 1706-1716, doi:10.1016/j.atmosenv.2006.10.030, 2007.

Adams, P. J., Seinfeld, J. H., and Koch, D. M.: Global concentrations of tropospheric sulfate, nitrate, and ammonium aerosol simulated in a general circulation model, J. Geophys. Res.-Atmos., 104, 13791-13823, 1999.

Amdur, M. O. and Chen, L. C.: Furnace-generated acid aerosols speciation and pulmonary effects, Environ. Health Perspect., 79, 147-150, 1989.

Arimoto, R., Duce, R. A., Savoie, D. L., Prospero, J. M., Talbot, R., Cullen, J. D., Tomza, U., Lewis, N. F., and Jay, B. J.: Relationships among aerosol constituents from Asia and the North Pacific during PEM-West A, J. Geophys. Res.-Atmos., 101, 2011-2023, 1996.

Asman, W. A. H., Sutton, M. A., and Schjorring, J. K.: Ammonia: emission, atmospheric transport and deposition, New Phytol., 139, 27-48, 1998.

Beijing Municipal Bureau of Statistics: Beijing statistical Yearbook, http://www.bjstats.gov.cn/tjnj/2006-tjnj, 2006 (in Chinese).

Bergin, M. H., Cass, G. R., Xu, J., Fang, C., Zeng, L. M., Yu, T., Salmon, L. G., Kiang, C. S., Tang, X. Y., Zhang, Y. H., and Chameides, W. L.: Aerosol radiative, physical, and chemical properties in Beijing during June 1999, J. Geophys. Res.-Atmos., 106, 17969-17980, 2001.

Boucher, O. and Anderson, T. L.: General circulation model assessment of the sensitivity of direct climate forcing by anthropogenic sulfate aerosols to aerosol size and chemistry, J. Geophys. Res.Atmos., 100, 26117-26134, 1995.

Chan, C. K. and Yao, X.: Air pollution in mega cities in China, Atmos. Environ., 42, 1-42, doi:10.1016/j.atmosenv.2007.09.003, 2008.

Cheung, H. C., Wang, T., Baumann, K., and Guo, H.: Influence of regional pollution outflow on the concentrations of fine particulate matter and visibility in the coastal area of southern China, Atmos. Environ., 39, 6463-6474, doi:10.1016/j.atmosenv.2005.07.033, 2005.

Chongqing Municipal Bureau of Statistics: Chongqing statistical Yearbook, http://www.cqtj.gov.cn/tjnj/2006/, 2006 (in Chinese).

Chou, C. C. K., Lee, C. T., Yuan, C. S., Hsu, W. C., Lin, C. Y., Hsu, S. C., and Liu, S. C.: Implications of the chemical transformation of Asian outflow aerosols for the long-range transport of inorganic nitrogen species, Atmos. Environ., 42, 7508-7519, doi:10.1016/j.atmosenv.2008.05.049, 2008.

Chu, S. H.: $\mathrm{PM}_{2.5}$ episodes as observed in the speciation trends network, Atmos. Environ., 38, 5237-5246, doi:10.1016/j.atmosenv.2004.01.055, 2004.

Clegg, S. L., Brimblecombe, P., and Wexler, A. S.: Thermodynamic model of the system $\mathrm{H}^{+}-\mathrm{NH}_{4}^{+}-\mathrm{SO}_{4}^{2}-\mathrm{NO}_{3}-\mathrm{H}_{2} \mathrm{O}$ at tropospheric temperatures, J. Phys. Chem. A, 102, 2137-2154, 1998.

Crumeyrolle, S., Gomes, L., Tulet, P., Matsuki, A., Schwarzenboeck, A., and Crahan, K.: Increase of the aerosol hygroscopicity by cloud processing in a mesoscale convective system: a case study from the AMMA campaign, Atmos. Chem. Phys., 8, 6907-6924, doi:10.5194/acp-8-6907-2008, 2008.

Dillner, A. M., Schauer, J. J., Zhang, Y. H., Zeng, L. M., and Cass, G. R.: Size-resolved particulate matter composition in Beijing during pollution and dust events, J. Geophys. Res.-Atmos., 111, D05203, doi:10.1029/2005jd006400, 2006.

Draxler, R. R., Stunder, B., Rolph, G., and Taylor, A.: HYSPLIT4 user's guide (online version), NOAA Tech. Memo. ERL ARL230., available at: http://www.arl.noaa.gov/data/web/models/ hysplit4/win95/user_guide.pdf, 2006.

Feng, J. L., Guo, Z. G., Chan, C. K., and Fang, M.: Properties of organic matter in $\mathrm{PM}_{2.5}$ at Changdao Island, China - A rural site in the transport path of the Asian continental outflow, Atmos. Environ., 41, 1924-1935, doi:10.1016/j.atmosenv.2006.10.064, 2007.

Gong, S. L., Zhang, X. Y., Zhao, T. L., Zhang, X. B., Barrie, L. A., McKendry, I. G., and Zhao, C. S.: A simulated climatology of Asian dust aerosol and its trans-Pacific transport. Part II: Interannual variability and climate connections, J. Climate, 19, 104-122, 2006.

Guo, S., Hu, M., Wang, Z. B., Slanina, J., and Zhao, Y. L.: Sizeresolved aerosol water-soluble ionic compositions in the summer of Beijing: implication of regional secondary formation, Atmos. Chem. Phys., 10, 947-959, doi:10.5194/acp-10-947-2010, 2010.

Han, J. S., Moon, K. J., Lee, S. J., Kim, Y. J., Ryu, S. Y., Cliff, S. S., and Yi, S. M.: Size-resolved source apportionment of ambient particles by positive matrix factorization at Gosan background site in East Asia, Atmos. Chem. Phys., 6, 211-223, doi:10.5194/acp-6-211-2006, 2006. 
He, K. B., Yang, F. M., Ma, Y. L., Zhang, Q., Yao, X. H., Chan, C. K., Cadle, S., Chan, T., and Mulawa, P.: The characteristics of $\mathrm{PM}_{2.5}$ in Beijing, China, Atmos. Environ., 35, 4959-4970, 2001.

He, K. B., Zhao, Q., Ma, Y. L., Duan, F. K., and Yang, F. M.: Seasonal composition and long-term trend of $\mathrm{PM}_{2.5}$ at Beijing and Chongqing, China, Atmos. Environ., submitted, 2011.

Health Effects Institute: Understanding the health effects of components of the particulate matter mix: progress and next steps, HEI Perspectives, 2002.

$\mathrm{Hu}$, J. H. and Abbatt, J. P. D.: Reaction probabilities for $\mathrm{N}_{2} \mathrm{O}_{5}$ hydrolysis on sulfuric acid and ammonium sulfate aerosols at room temperature, J. Phys. Chem. A, 101, 871-878, 1997.

Huang, M. Y., Shen, Z. L., Wu, Y. X., Luo, Q. R., Xu, Y., Zhang, D. B., and Chen, S. L.: Observation on the acidity and chemical compositions of cloudwater and rainwater over Chongqing, Scientia Atmospherica Sinica, 12, 389-395, 1988.

Jang, M. S., Czoschke, N. M., Lee, S., and Kamens, R. M.: Heterogeneous atmospheric aerosol production by acid-catalyzed particle-phase reactions, Science, 298, 814-817, 2002.

Jia, Y. T., Rahn, K. A., He, K. B., Wen, T. X., and Wang, Y. S.: A novel technique for quantifying the regional component of urban aerosol solely from its sawtooth cycles, J. Geophys. Res.-Atmos., 113, D21309, doi:10.1029/2008jd010389, 2008.

Jickells, T. D., An, Z. S., Andersen, K. K., Baker, A. R., Bergametti, G., Brooks, N., Cao, J. J., Boyd, P. W., Duce, R. A., Hunter, K. A., Kawahata, H., Kubilay, N., LaRoche, J., Liss, P. S., Mahowald, N., Prospero, J. M., Ridgwell, A. J., Tegen, I., and Torres, R.: Global iron connections between desert dust, ocean biogeochemistry, and climate, Science, 308, 67-71, 2005.

Johansen, A. M., Siefert, R. L., and Hoffmann, M. R.: Chemical characterization of ambient aerosol collected during the southwest monsoon and intermonsoon seasons over the Arabian Sea: Anions and cations, J. Geophys. Res.-Atmos., 104, 2632526347, 1999.

John, W., Wall, S. M., Ondo, J. L., and Winklmayr, W.: Modes in the size distributions of atmospheric inorganic aerosol, Atmos. Environ. A-Gen., 24, 2349-2359, 1990.

Larssen, T., Lydersen, E., Tang, D. G., He, Y., Gao, J. X., Liu, H. Y., Duan, L., Seip, H. M., Vogt, R. D., Mulder, J., Shao, M., Wang, Y. H., Shang, H., Zhang, X. S., Solberg, S., Aas, W., Okland, T., Eilertsen, O., Angell, V., Liu, Q. R., Zhao, D. W., Xiang, R. J., Xiao, J. S., and Luo, J. H.: Acid rain in China, Environ. Sci. Technol., 40, 418-425, 2006.

Li, W. J. and Shao, L. Y.: Observation of nitrate coatings on atmospheric mineral dust particles, Atmos. Chem. Phys., 9, $1863-$ 1871, doi:10.5194/acp-9-1863-2009, 2009.

Li, X. G., Wang, S. X., Duan, L., Hao, J., Li, C., Chen, Y. S., and Yang, L.: Particulate and trace gas emissions from open burning of wheat straw and corn stover in China, Environ. Sci. Technol., 41, 6052-6058, doi:10.1021/es0705137, 2007.

Li, X. H., Wang, S. X., Duan, L., Hao, J. M., and Nie, Y. F.: Carbonaceous Aerosol Emissions from Household Biofuel Combustion in China, Environ. Sci. Technol., 43, 6076-6081, doi:10.1021/es803330j, 2009.

Liu, L. J. S., Burton, R., Wilson, W. E., and Koutrakis, P.: Comparison of aerosol acidity in urban and semirural environments, Atmos. Environ., 30, 1237-1245, 1996.

Liu, S. R. and Huang, M. Y.: Numerical simulation on the acidification of rainwater under cloud and formation of acid rain in
Chongqing, Scientia Atmospherica Sinica, 12, 245-257, 1988.

Louie, P. K. K., Chow, J. C., Chen, L. W. A., Watson, J. G., Leung, G., and Sin, D. W. M.: $\mathrm{PM}_{2.5}$ chemical composition in Hong Kong: Urban and regional variations, Sci. Total Environ., 338, 267-281, 2005.

Lu, X. Y., Zhang, X. Z., and Chen, J. N.: Study on the anomaly of the East Asian summer monsoon in June 2005 and the affecting mechanism, J. Trop. Meteorol., 23, 553-562, 2007 (in Chinese with abstract in English).

Luo, C., Zender, C. S., Bian, H. S., and Metzger, S.: Role of ammonia chemistry and coarse mode aerosols in global climatological inorganic aerosol distributions, Atmos. Environ., 41, 2510-2533, doi:10.1016/j.atmosenv.2006.11.030, 2007.

Meng, Z. Y., Seinfeld, J. H., Saxena, P., and Kim, Y. P.: Atmospheric gas-aerosol equilibrium .4. thermodynamics of carbonates, Aerosol Sci. Technol., 23, 131-154, 1995.

Meng, Z. Y., Xu, X. B., Wang, T., Zhang, X. Y., Yu, X. L., Wang, S. F., Lin, W. L., Chen, Y. Z., Jiang, Y. A., and An, X. Q.: Ambient sulfur dioxide, nitrogen dioxide, and ammonia at ten background and rural sites in China during 2007-2008, Atmos. Environ., 44, 2625-2631, doi:10.1016/j.atmosenv.2010.04.008, 2010.

Meskhidze, N., Chameides, W. L., and Nenes, A.: Dust and pollution: A recipe for enhanced ocean fertilization?, J. Geophys. Res., 110, D03301, doi:10.1029/2004JD005082, 2005.

Mu, J. L., Wang, J. J., and Li, Z. C.: A study of environment and mesoscale convective systems of continuous heavy rainfall in the South of China in June 2005, Acta Meteorol. Sin., 66, 437-451, 2008.

Nenes, A., Pandis, S. N., and Pilinis, C.: ISORROPIA: A new thermodynamic equilibrium model for multiphase multicomponent inorganic aerosols, Aquat. Geochem., 4, 123-152, 1998.

Nenes, A., Krom, M. D., Mihalopoulos, N., Van Cappellen, P., Shi, Z., Bougiatioti, A., Zarmpas, P., and Herut, B.: Atmospheric acidification of mineral aerosols: a source of bioavailable phosphorus for the oceans, Atmos. Chem. Phys., 11, 6265-6272, doi:10.5194/acp-11-6265-2011, 2011.

Ooki, A. and Uematsu, M.: Chemical interactions between mineral dust particles and acid gases during Asian dust events, J. Geophys. Res.-Atmos., 110, D03201, doi:10.1029/2004jd004737, 2005.

Pakkanen, T. A., Kerminen, V. M., Hillamo, R. E., Makinen, M., Makela, T., and Virkkula, A.: Distribution of nitrate over seasalt and soil derived particles - Implications from a field study, J. Atmos. Chem., 24, 189-205, 1996.

Pathak, R. K., Yao, X. H., Lau, A. K. H., and Chan, C. K.: Acidity and concentrations of ionic species of $\mathrm{PM}_{2.5}$ in Hong Kong, Atmos. Environ., 37, 1113-1124, doi:10.1016/s13522310(02)00958-5, 2003.

Pathak, R. K., Louie, P. K. K., and Chan, C. K.: Characteristics of aerosol acidity in Hong Kong, Atmos. Environ., 38, 2965-2974, doi:10.1016/j.atmosenv.2004.02.044, 2004a.

Pathak, R. K., Yao, X. H., and Chan, C. K.: Sampling artifacts of acidity and ionic species in $\mathrm{PM}_{2.5}$, Environ. Sci. Technol., 38, 254-259, doi:10.1021/es0342244, 2004b.

Pathak, R. K., Wu, W. S., and Wang, T.: Summertime $\mathrm{PM}_{2.5}$ ionic species in four major cities of China: nitrate formation in an ammonia-deficient atmosphere, Atmos. Chem. Phys., 9, 17111722, doi:10.5194/acp-9-1711-2009, 2009.

Quan, H. N. and Zhang, X. S.: Assessing the role of ammonia in 
sulfur transformation and deposition in China, Atmos. Res., 88, 78-88, doi:10.1016/j.atmosres.2007.10.006, 2008.

Richter, A., Burrows, J. P., Nuss, H., Granier, C., and Niemeier, U.: Increase in tropospheric nitrogen dioxide over China observed from space, Nature, 437, 129-132, doi:10.1038/nature04092, 2005.

Roger, G. B. and Andrew, M. C.: Synoptic and dynamic climatology, New York, Routledge, 735-876, 2002.

Seinfeld, J. H. and Pandis, S. N.: Atmos. Chem. Phys.: From Air Pollution to Climate Change, New York, Wiley, 1998.

Shen, Z. L., Wu, Y. X., Xiao, H., and Huang, M. Y.: Annual variation of chemical characteristics of cloudwater in Chongqing area, Acta Scientiae Circumstantiae, 12, 193-199, 1992.

Shen, Z. X., Arimoto, R., Cao, J. J., Zhang, R. J., Li, X. X., Du, N., Okuda, T., Nakao, S., and Tanaka, S.: Seasonal Variations and Evidence for the Effectiveness of Pollution Controls on WaterSoluble Inorganic Species in Total Suspended Particulates and Fine Particulate Matter from Xi' an, China, J. Air Waste Manage., 58, 1560-1570, doi:10.3155/1047-3289.58.12.1560, 2008.

Shi, Z., Bonneville, S., Krom, M. D., Carslaw, K. S., Jickells, T. D., Baker, A. R., and Benning, L. G.: Iron dissolution kinetics of mineral dust at low $\mathrm{pH}$ during simulated atmospheric processing, Atmos. Chem. Phys., 11, 995-1007, doi:10.5194/acp11-995-2011, 2011.

Song, C. H., Park, M. E., Lee, K. H., Ahn, H. J., Lee, Y., Kim, J. Y., Han, K. M., Kim, J., Ghim, Y. S., and Kim, Y. J.: An investigation into seasonal and regional aerosol characteristics in East Asia using model-predicted and remotely-sensed aerosol properties, Atmos. Chem. Phys., 8, 6627-6654, doi:10.5194/acp8-6627-2008, 2008.

Stohl, A.: Computation, accuracy and applications of trajectories A review and bibliography, Atmos. Environ., 32, 947-966, 1998.

Sun, J. Y., Zhang, Q., Canagaratna, M. R., Zhang, Y. M., Ng, N. L., Sun, Y. L., Jayne, J. T., Zhang, X. C., Zhang, X. Y., and Worsnop, D. R.: Highly time- and size-resolved characterization of submicron aerosol particles in Beijing using an Aerodyne Aerosol Mass Spectrometer, Atmos. Environ., 44, 131-140, doi:10.1016/j.atmosenv.2009.03.020, 2010.

Sun, Y. L., Zhuang, G. S., Wang, Z. F., Wang, Y., Zhang, W. J., Tang, A. H., Zhao, X. J., and Jia, L.: Regional characteristics of spring Asian dust and its impact on aerosol chemistry over northern China, Atmos. Chem. Phys. Discuss., 6, 12825-12864, doi:10.5194/acpd-6-12825-2006, 2006.

Takahama, S., Davidson, C. I., and Pandis, S. N.: Semicontinuous measurements of organic carbon and acidity during the Pittsburgh air quality study: Implications for acid-catalyzed organic aerosol formation, Environ. Sci. Technol., 40, 2191-2199, doi:10.1021/es050856+, 2006.

Takami, A., Miyoshi, T., Shimono, A., Kaneyasu, N., Kato, S., Kajii, Y., and Hatakeyama, S.: Transport of anthropogenic aerosols from Asia and subsequent chemical transformation, J. Geophys. Res.-Atmos., 112, D22S31, doi:10.1029/2006jd008120, 2007.

Vlasenko, A., Sjogren, S., Weingartner, E., Stemmler, K., Gäggeler, H. W., and Ammann, M.: Effect of humidity on nitric acid uptake to mineral dust aerosol particles, Atmos. Chem. Phys., 6, 21472160, doi:10.5194/acp-6-2147-2006, 2006.

Wai, K. M. and Tanner, P. A.: Relationship between ionic composition in $\mathrm{PM}_{10}$ and the synoptic-scale and mesoscale weather conditions in a south China coastal city: A 4-year study, J. Geophys.
Res.-Atmos., 110, D18210, doi:10.1029/2004jd005385, 2005.

Wang, W., Jiang, Z. Y., Zhang, M. H., and Wang, W. X.: Pollution characteristic of atmospheric aerosol and relationship between aerosol and acid precipitation in south China, J. Environ. Sci., 12, 7-15, 1992 (in Chinese with abstract in English).

Wang, W., Tang, D. G., Liu, H. J., Yue, X., Pan, Z., and Ding, Y.: Research on Corrent Pollution Sataus and Pollution, Characteristic s of $\mathrm{PM}_{2.5}$ in China, Res. Environ. Sci., 13, 1-5, 2000 (in Chinese with abstract in English).

Wang, Y., Zhuang, G. S., Tang, A. H., Yuan, H., Sun, Y. L., Chen, S. A., and Zheng, A. H.: The ion chemistry and the source of $\mathrm{PM}_{2.5}$ aerosol in Beijing, Atmos. Environ., 39, 3771-3784, doi:10.1016/j.atmosenv.2005.03.013, 2005.

Wang, Y., Zhuang, G. S., Zhang, X. Y., Huang, K., Xu, C., Tang, A. H., Chen, J. M., and An, Z. S.: The ion chemistry, seasonal cycle, and sources of $\mathrm{PM}_{2.5}$ and TSP aerosol in Shanghai, Atmos. Environ., 40, 2935-2952, doi:10.1016/j.atmosenv.2005.12.051, 2006.

Watson, J. G.: Visibility: Science and Regulation, J. Air Waste Manage., 52, 628-713, 2002.

Wu, D., Tie, X. X., and Deng, X. J.: Chemical characterizations of soluble aerosols in southern China, Chemosphere, 64, 749-757, doi:10.1016/j.chemosphere.2005.11.066, 2006.

Wu, Z. J., Cheng, Y. F., Hu, M., Wehner, B., Sugimoto, N., and Wiedensohler, A.: Dust events in Beijing, China (20042006): comparison of ground-based measurements with columnar integrated observations, Atmos. Chem. Phys., 9, 6915-6932, doi:10.5194/acp-9-6915-2009, 2009.

Xin, J. Y., Wang, Y. S., Li, Z. Q., Wang, P. C., Hao, W. M., Nordgren, B. L., Wang, S. G., Liu, G. R., Wang, L. L., Wen, T. X., Sun, Y., and Hu, B.: Aerosol optical depth (AOD) and Angstrom exponent of aerosols observed by the Chinese Sun Hazemeter Network from August 2004 to September 2005, J. Geophys. Res.-Atmos., 112, D05203, doi:10.1029/2006jd007075, 2007.

Xiu, G. L., Zhang, D. N., Chen, J. Z., Huang, X. J., Chen, Z. X., Guo, H. L., and Pan, J. F.: Characterization of major watersoluble inorganic ions in size-fractionated particulate matters in Shanghai campus ambient air, Atmos. Environ., 38, 227-236, doi:10.1016/j.atmosenv.2003.09.053, 2004.

Yang, H., Yu, J. Z., Ho, S. S. H., Xu, J. H., Wu, W. S., Wan, C. H., Wang, X. D., Wang, X. R., and Wang, L. S.: The chemical composition of inorganic and carbonaceous materials in $\mathrm{PM}_{2.5}$ in Nanjing, China, Atmos. Environ., 39, 3735-3749, doi:10.1016/j.atmosenv.2005.03.010, 2005.

Yang, L. X., Wang, D. C., Cheng, S. H., Wang, Z., Zhou, Y., Zhou, X. H., and Wang, W. X.: Influence of meteorological conditions and particulate matter on visual range impairment in Jinan, China, Sci. Total Environ., 383, 164-173, doi:10.1016/j.scitotenv.2007.04.042, 2007.

Yao, X. H., Chan, C. K., Fang, M., Cadle, S., Chan, T., Mulawa, P., He, K. B., and Ye, B. M.: The water-soluble ionic composition of $\mathrm{PM}_{2.5}$ in Shanghai and Beijing, China, Atmos. Environ., 36, 4223-4234, 2002.

Yao, X. H., Lau, A. P. S., Fang, M., Chan, C. K., and Hu, M.: Size distributions and formation of ionic species in atmospheric particulate pollutants in Beijing, China: 1 - inorganic ions, Atmos. Environ., 37, 2991-3000, doi:10.1016/s1352-2310(03)00255-3, 2003.

Yao, X. H., Ling, T. Y., Fang, M., and Chan, C. K.: Comparison 
of thermodynamic predictions for in situ $\mathrm{pH}$ in $\mathrm{PM}_{2.5}$, Atmos. Environ., 40, 2835-2844, doi:10.1016/j.atmosenv.2006.01.006, 2006.

Ye, B. M., Ji, X. L., Yang, H. Z., Yao, X. H., Chan, C. K., Cadle, S. H., Chan, T., and Mulawa, P. A.: Concentration and chemical composition of $\mathrm{PM}_{2.5}$ in Shanghai for a 1-year period, Atmos. Environ., 37, 499-510, 2003.

Zhang, L., Liao, H., and Li, J. P.: Impacts of Asian summer monsoon on seasonal and interannual variations of aerosols over eastern China, J. Geophys. Res.-Atmos., 115, D00K05, doi:10.1029/2009jd012299, 2010.

Zhang, Q., Jimenez, J. L., Worsnop, D. R., and Canagaratna, M.: A case study of urban particle acidity and its influence on secondary organic aerosol, Environ. Sci. Technol., 41, 3213-3219, doi:10.1021/es061812j, 2007a.

Zhang, Q., Streets, D. G., He, K., Wang, Y., Richter, A., Burrows, J. P., Uno, I., Jang, C. J., Chen, D., Yao, Z., and Lei, Y.: NO $\mathrm{NO}_{\mathrm{x}}$ emission trends for China, 1995-2004: The view from the ground and the view from space, J. Geophys. Res.-Atmos., 112, D22306, doi:10.1029/2007jd008684, 2007b.

Zhang, X. Y., Cao, J. J., Li, L. M., Arimoto, R., Cheng, Y., Huebert, B., and Wang, D.: Characterization of Atmospheric Aerosol over XiAn in the South Margin of the Loess Plateau, China, Atmos. Environ., 36, 4189-4199, 2002.
Zhao, D. W., Seip, H. M., and Zhang, D. B.: Pattern and cause of acidic deposition in the chongqing region, sichuan-province, china, Water Air Soil Poll., 77, 27-48, 1994.

Zhao, Q., He, K. B., Ma, Y. L., Jia, Y. T., Cheng, Y., Liu, H., and Wang, S. W.: Regional PM Pollution in Beijing and Surrounding Area During Summertime, Environ. Sci., 30, 1873-1880, 2009.

Zhao, Q., He, K., Rahn, K. A., Ma, Y., Jia, Y., Yang, F., Duan, F., Lei, Y., Chen, G., Cheng, Y., Liu, H., and Wang, S.: Dust storms come to Central and Southwestern China, too: implications from a major dust event in Chongqing, Atmos. Chem. Phys., 10, 26152630, doi:10.5194/acp-10-2615-2010, 2010.

Zhuang, H., Chan, C. K., Fang, M., and Wexler, A. S.: Formation of nitrate and non-sea-salt sulfate on coarse particles, Atmos. Environ., 33, 4223-4233, 1999.

Ziemba, L. D., Fischer, E., Griffin, R. J., and Talbot, R. W.: Aerosol acidity in rural New England: Temporal trends and source region analysis, J. Geophys. Res.-Atmos., 112, D10S22, doi:10.1029/2006jd007605, 2007. 